\title{
13. PALEOGENE ABYSSAL FORAMINIFERS FROM THE CAPE AND ANGOLA BASINS, SOUTH ATLANTIC OCEAN1
}

\author{
Murlene W. Clark, ${ }^{2}$ Florida State University, Tallahassee, Florida \\ and \\ Ramil C. Wright, Exxon Production Research Company, Houston, Texas
}

\begin{abstract}
The recovery of calcareous-rich sediments of Paleogene age from three sites in the eastern South Atlantic Ocean provided the opportunity to document the rich abyssal benthic foraminiferal fauna contained within them. The faunal dominance patterns observed at these sites are generally similar to those observed elsewhere in the abyssal Atlantic. There is no unusual faunal turnover at the Oligocene/Eocene boundary, although faunal changes are marked between the middle and upper Eocene.
\end{abstract}

\section{INTRODUCTION}

Benthic foraminifers were examined from three DSDP sites (522, 523, and 524) in the Cape and Angola Basins (Fig. 1) to determine the changes that took place in the Paleogene abyssal population through time. The abyssal environment is one of the most uniform in the ocean; major alterations in diversity and dominance in the deep assemblage can be used as an index of global paleoceanographic changes.

Paleodepths were estimated for Sites 522 and 523 by using the backtracking methods developed by Berger and von Rad (1972). As a result of crustal cooling, the seafloor sank from approximately 2200 to $3600 \mathrm{~m}$ below sea level during the Paleogene at Site 522 and from 2200 to $3600 \mathrm{~m}$ below sea level at Site 523 . Because Site 524 lies on the flanks of the Walvis Ridge, changes in paleodepth due to crustal cooling could not be calculated. The Paleocene and lower Eocene sediments at this site exhibit a "Velasco" type of fauna, and the sediments are therefore considered to be deep (probably abyssal) water deposits.

A Paleogene section was recovered from the Cape and Angola Basins that was complete with the exception of the uppermost portion of the lower Eocene (NP12 to NP14). The sediments were dated biostratigraphically by using calcareous nannofossil and planktonic foraminifers.

Faunal comparisons like those made by Proto Decima and Bolli (1978) could not be made between the Cape and Angola Basins, because coeval sections were not available. Paleocene and lower Eocene sediments were recovered from the Cape Basin, whereas middle Eocene through Oligocene sections were sampled in the Angola Basin. General comparisons can be made between the South Atlantic Paleogene abyssal fauna and the fauna of contemporaneous land sections in the $\mathrm{Ca}$ -

\footnotetext{
1 Hsï, K. J., LaBrecque, J. L., et al., Init. Repts. DSDP, 73: Washington (U.S. Govt. Printing Office)

2 Present address: Union Oil of California, Houston, Texas.
}

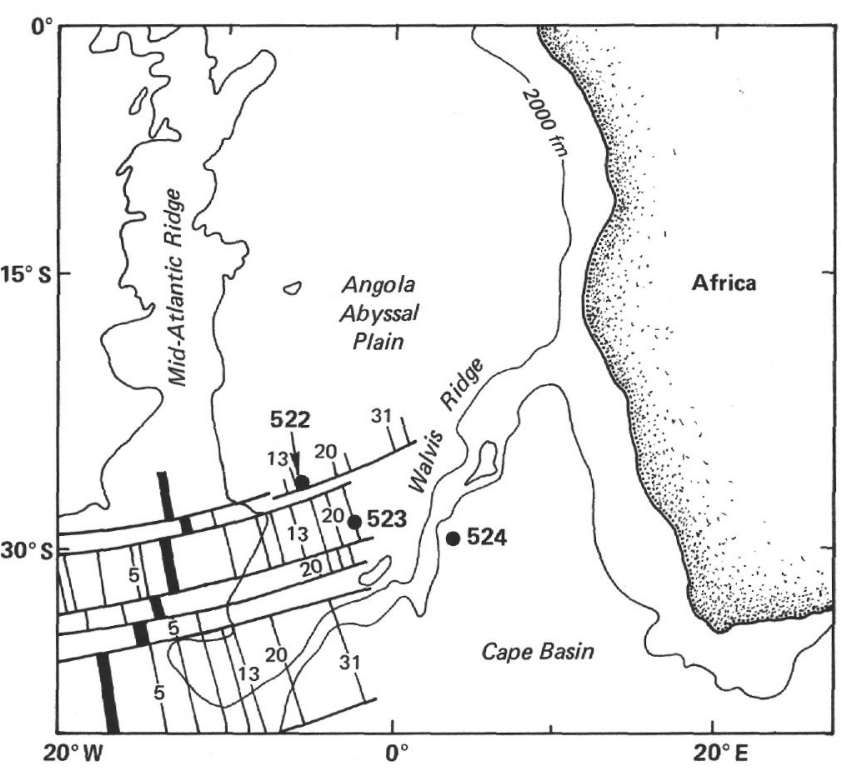

Figure 1. Location map showing positions of sites, marine magnetic anomalies, and the $2000 \mathrm{fm}$ bathymetric contour.

ribbean, particularly Barbados, the Dominican Republic, Trinidad, Cuba, and Mexico.

\section{METHODS}

Benthic foraminifers were identified and counted from the $>125$ $\mu \mathrm{m}$ size fraction; a taxonomy is presented in the appendix, and range and abundance data are shown in Figures 2 to 4 . As a general rule, species that occur in trace quantities are not cited. With a few exceptions, Lagena, Fissurina, Oolina, Parafissurina, and Polymorphinidae are also omitted because of their great diversity and cosmopolitan distribution. These taxa collectively never comprise more than $5 \%$ of any sample.

\section{PRESERVATION}

Preservation at Sites 522 and 523 is generally good, although dissolution caused preservation to be poor to moderate during brief intervals of the Paleogene. The samples at Site 524 are less well preserved; calcareous overgrowths occasionally obscure fine detail in the spec- 


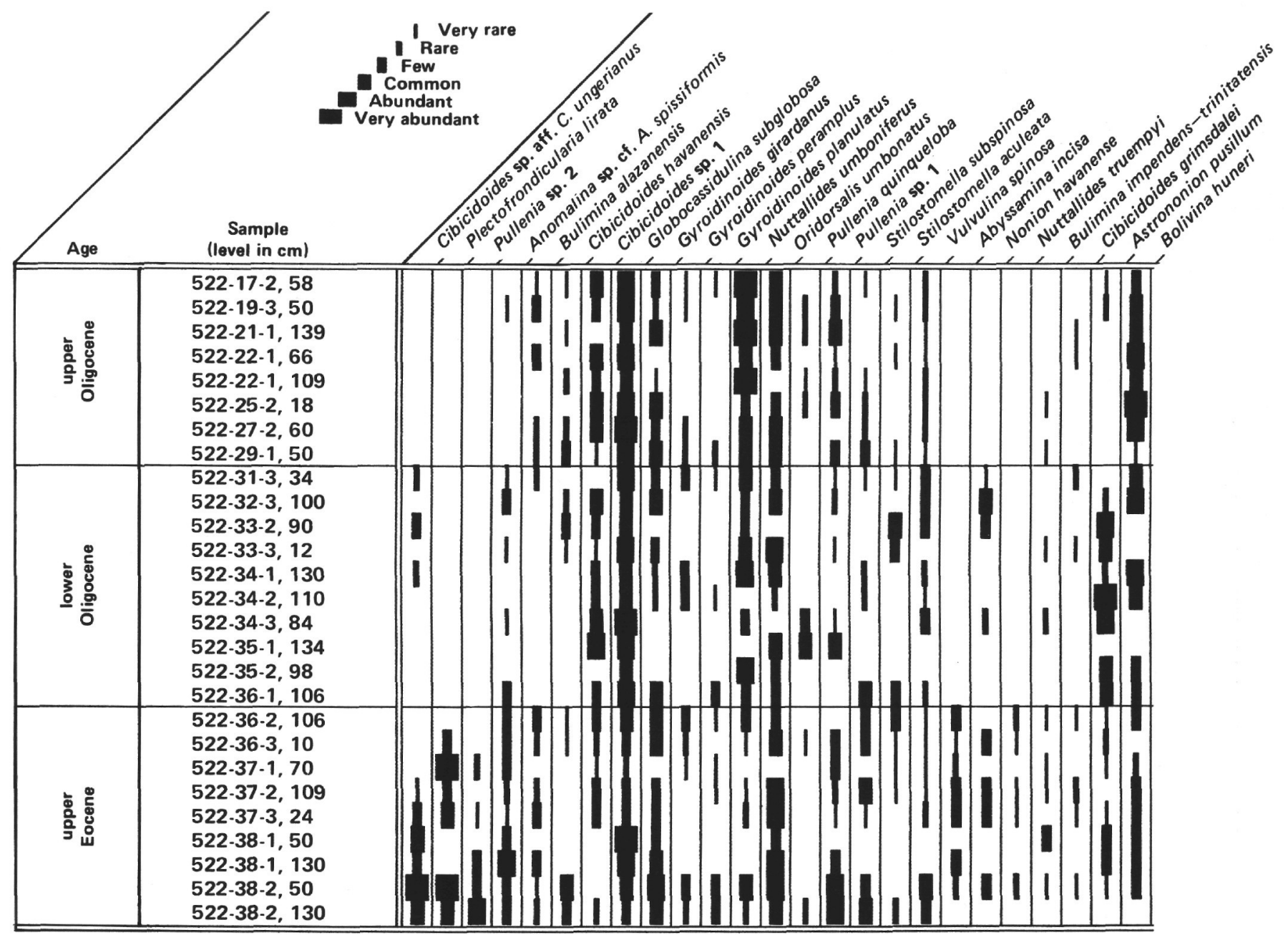

Figure 2. Paleogene benthic foraminifers in Hole 522. The width of each bar is proportional to abundance, which is defined as follows: very rare$<1 \%$; rare $-1-2 \%$; few $-2-5 \%$; common $-5-10 \%$; abundant -10 to $20 \%$; very abundant $\rightarrow 20 \%$.

imens. As the plates illustrate, a light coating of calcareous nannofossils and calcareous debris clings to the etched tests of some of the foraminifers.

\section{CHANGES IN FAUNAL ASSEMBLAGE}

The Paleocene fauna is dominated by Gavelinella beccariiformis, Nuttallides crassaformis-truempyi, and (to a lesser degree) by Neoeponides hillebrandti and Spiroplectammina spectabilis. A bloom of Hanzawaia and Cibicides in Zones NP3 through NP5 briefly eclipses all other forms. Tjalsma and Lohmann (1983) described $G$. beccariiformis and Tritaxia trilatera as the dominant species of the abyssal Paleocene. The first of these is abundant at Site 524, but the latter is not.

The lower Eocene sediments are characterized by a fauna that is somewhat less diverse than that of the Paleocene. The dominant taxon is clearly $N$. crassaformis-truempyi; the remainder of the assemblage is composed of survivors from the Paleocene, with the exception of Globocassidulina subglobosa, Aragonia semireticulata, Clinapertina inflata, and Hanzawaia cushmani, which originate at this time. Tappanina selmensis, Abyssamina quadrata, and Anomalina sp. cf. A. praeacuta are well represented in the assemblages. The lower Eo- cene assemblage at Site 524 is analogous to that described by Tjalsma and Lohmann (1983) by virtue of the dominant position of $N$. truempyi. In the Bay of Biscay, Miller (in press) also found abundant $N$. truempyi in the lower Eocene. In addition, he noted large quantities of Abyssamina spp. and Clinapertina spp., forms that are not particularly common at Site 524 .

During the middle Eocene, $N$. crassaformis-truempyi continued to dominate. This observation is consistent with that of Tjalsma and Lohmann (1983) and Miller (in press) for the same interval. The Leg 73 material also contains significant numbers of G. subglobosa, Gyroidinoides, and Oridorsalis umbonatus, taxa that were destined to assume prominant positions in the late Eocene fauna.

A change is apparent in the character of the abyssal assemblage during the upper Eocene. $N$. crassaformistruempyi, which dominated the Paleogene assemblages until this time, shows a marked decline in abundance. This event is coincident with the rise of $N$. umboniferus. Globocassidulina subglobosa, Gyroidinoides, O. umbonatus, and Cibicidoides sp. cf. $C$. ungerianus are also prominent in the upper Eocene assemblages. Bolivina huneri is important but secondary to the aforesaid spe- 


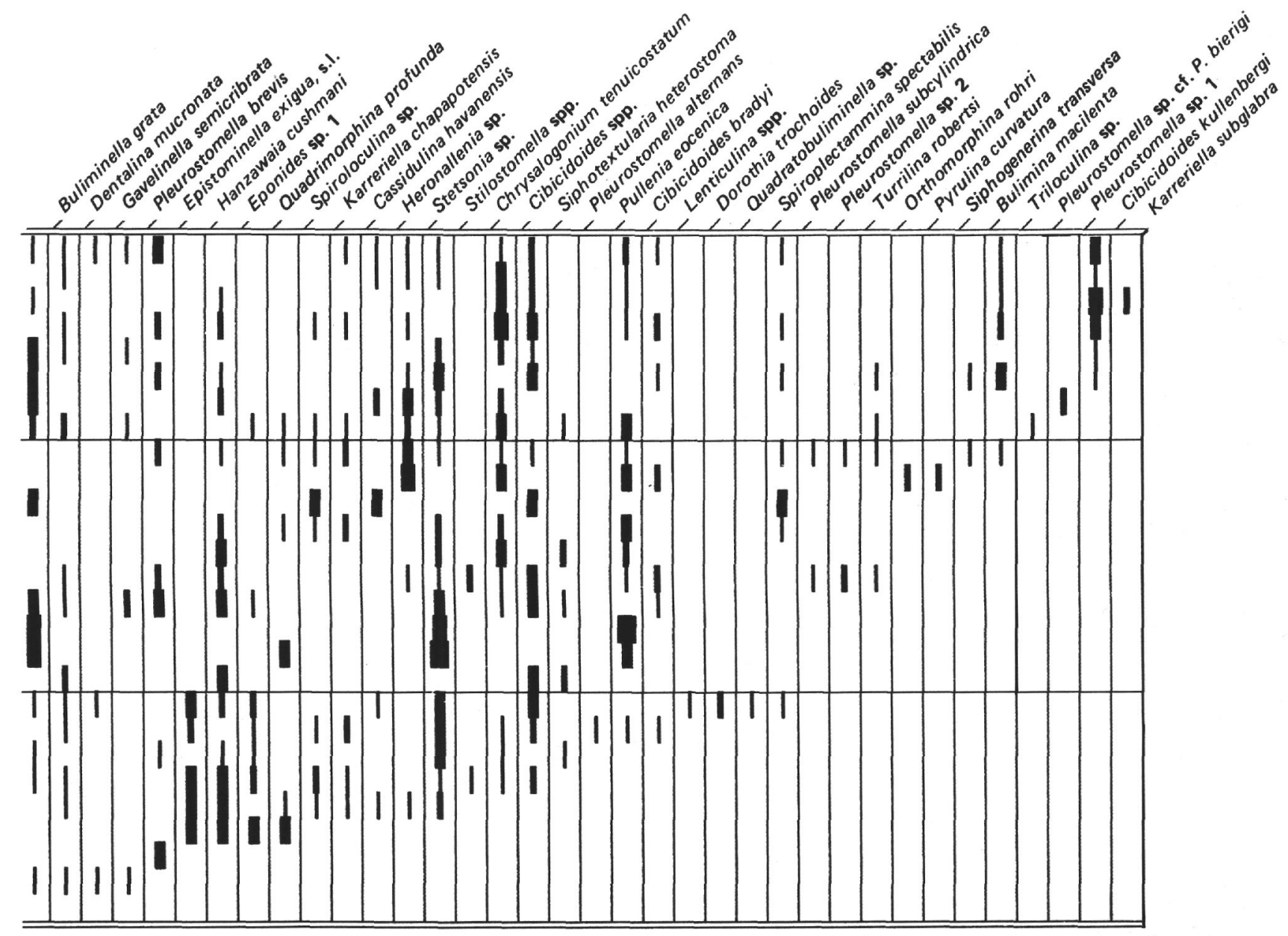

Figure 2. (Continued).

cies. A brief interval coinciding with Zone NP20 witnessed an additional perturbation from the patterns of dominance previously established during the Paleogene. Plectofrondicularia lirata increased dramatically, making up to $70 \%$ in some samples; this event occurred simultaneously with an increase in the abundance of Vulvulina spinosa.

The Oligocene faunal patterns are similar to those of the upper Eocene. Globocassidulina subglobosa, $O$. umbonatus, and Cibicidoides sp. 1 continue to dominate the assemblage. One prominant new faunal element is $N$. umboniferus, which originates in the late Eocene. Gyroidinoides is still well represented, but it assumes secondary significance. These Oligocene and upper Eocene patterns again are similar to those observed elsewhere in the Atlantic by Tjalsma (pers. comm., 1982), Tjalsma and Lohmann (1983), and Miller (in press).

There is no appreciable faunal turnover at the Oligocene/Eocene boundary. Our data here support similar observations made by Beckmann et al. (1981), Corliss (1981), and Tjalsma (pers. comm., 1982). Tjalsma and Lohmann (1983) concluded that a faunal turnover event took place earlier, between the middle and late Eocene. This event involved a change from a fauna dominated by $N$. truempyi to one dominated by Globocassidulina subglobosa, O. umbonatus, Gyroidinoides, and C. ungerianus. The data from Leg 73 show a high rate of faunal turnover at the upper/middle Eocene boundary (Parker et al., this vol.) in addition to the changes in assemblage dominance noted by Tjalsma and Lohmann (1983). There is also an extremely low species origination rate for the Oligocene that may be in response to the development of a psychrospheric ocean at this time (Parker et al., this vol.).

\section{TAXONOMY}

Taxonomic references can be found in Ellis and Messina (1940).

Abyssamina incisa Schnitker and Tjalsma (Plate 1, Figs. 1a-c). Intermediate forms between Abyssamina poagi and $A$. incisa (Schnitker and Tjalsma, 1980) are here included with $A$. incisa. $A$. incisa and transitional forms with increasingly incised sutures and more elongate final chambers occur most frequently in the upper middle and upper Eocene.

Abyssamina poagi Schnitker and Tjalsma (Plate 1, Figs. 2a-c).

Abyssamina quadrata Schnitker and Tjalsma (Plate 1, Figs. 3a-c). 


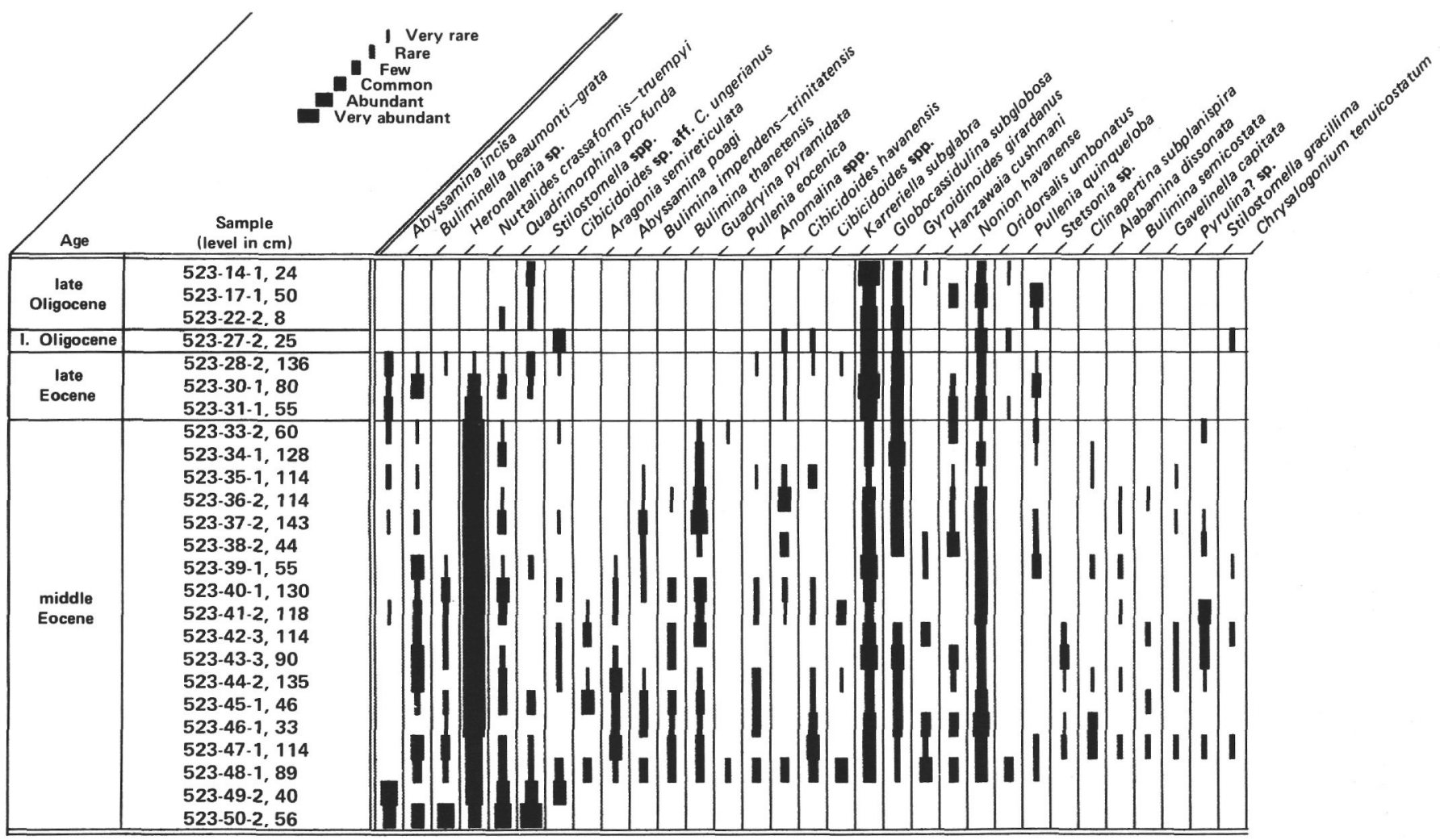

Figure 3. Paleogene benthic foraminifers in Hole 523. Abundance is defined as for Fig. 2.

Alabamina dissonata (Cushman and Renz) (Plate 2, Figs. $5 \mathrm{a}, \mathrm{b})[=$ Pulvinulinella atlantisae Cushman var. dissonata Cushman and Renz].

Anomalina sp. cf. A. praeacuta Vasilenko (Plate 2, Figs. $1 \mathrm{a}-\mathrm{c})$. The Leg 73 individuals have fewer chambers (10) than the type description indicates.

Anomalina sp. cf. A. spissiformis Cushman and Stainforth (Plate 1, Figs. 5a-c) [ = Anomalina alazanensis Nuttall var. spissiformis Cushman and Stainforth]. The Leg 73 specimens are smaller and have fewer chambers $(9-10)$ than specified by the type description.

Anomalina sp. 1 (Plate 2, Figs. 6a, b). This form is very nearly planispiral; the spiral side is very nearly involute. This species occurs only in the upper Paleocene of Site 524.

Anomalina sp. 2 (Plate 1, Figs. 4a-c). This species is similar in form to Gyroidinoides except for the anomalinid aperture. The form is subconical on the umbilical side. Chamber expansion is rapid, and the apertural face is large.

Aragonia capdevilensis (Cushman and Bermudez) (Plate 2, Figs. $4 \mathrm{a}, \mathrm{b})[=$ Bolivina capdevilensis Cushman and Bermudez]. The specimens are somewhat thickened at the apertural end.

Aragonia ouezzanensis (Rey) (Plate 2, Figs. 3a, b) [= Bolivinoides ouezzanensis Rey].

Aragonia semireticulata (LeRoy) (Plate 2, Figs. 2a, b) [ = Bolivina semireticulata LeRoy].

Astrononion pusillum Hornibrook (Plate 3, Figs. 1a, b).
Bolivina huneri Howe (Plate 3, Fig. 2). Ornamentation is usually absent from the last chamber; however, the penultimate chamber may be either smooth or ornamented. Resig (1976) described this form from the upper Eocene to lower Oligocene sediments of the Nazca Plate and called it Bolivina sp.

Bolivina sp. cf. B. spiralis Cushman (Plate 3, Fig. 3). The Leg 73 specimens lack the spines that Cushman described on the early portion of the test. Mallory (1959) illustrated a spineless form similar to the ones illustrated here and also cited it as Bolivina spiralis.

Bolivinoides delicatulus Cushman $[=$ Bolivinoides decorata (Jones) var. delicatula Cushman].

Bulimina alazanensis Cushman (Plate 3, Figs. 4a, b).

Bulimina bradburyi Martin (Plate 3, Fig. 5). The early chambers of this form sometimes show a rough texture, although this may be a function of preservation.

Bulimina impendens Parker and Bermudez (Plate 3, Fig. 6). Bulimina impendens appears to be gradational with $B$. trinitatensis. The two forms are very similar and are tabulated here under the designation $B$. impendens-trinitatensis. B. impendens, s.s., which is very rare in the Leg 73 material, is less elongate and has fewer chambers than $B$. trinitatensis.

Bulimina macilenta Cushman and Parker [= Bulimina denticulata Cushman and Parker (non Protescu), Bulimina macilenta Cushman and Parker].

Bulimina midwayensis Cushman and Parker (Plate 3, Fig. 7) [= Bulimina arkadelphiana Cushman and Parker var. midwayensis Cushman and Parker]. 


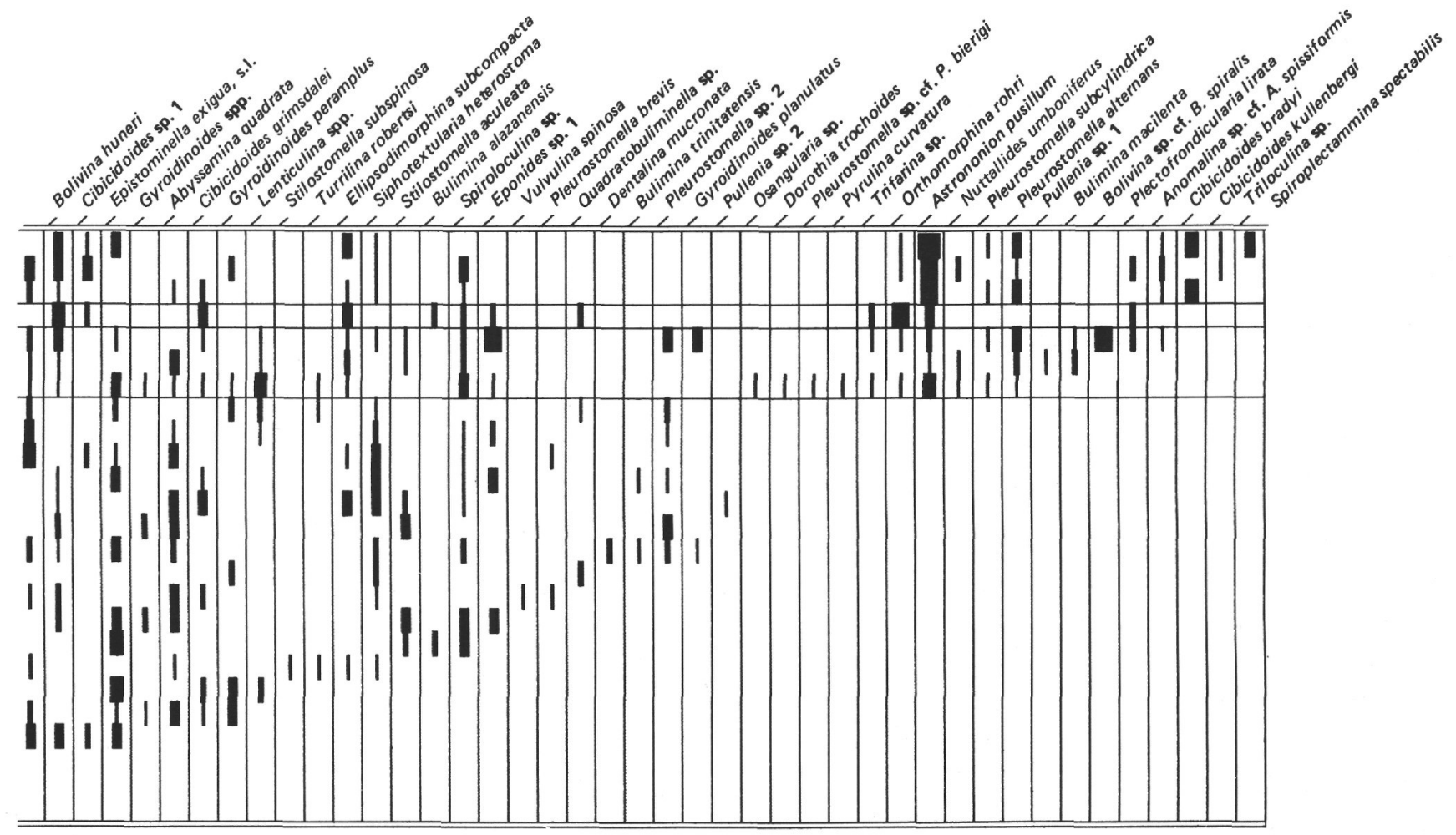

Figure 3. (Continued).

Bulimina semicostata Nuttall (Plate 3, Fig. 8).

Bulimina thanetensis Cushman and Parker (Plate 3, Fig. 10).

Bulimina trihedra Cushman.

Bulimina trinitatensis Cushman and Jarvis (Plate 3, Fig.

9). This species is combined with Bulimina impen-

dens for tabulation in the range charts for Sites 522

and 523. The species is more elongate and has more chambers than $B$. impendens.

Buliminella beaumonti Cushman and Renz (Plate 3, Fig. 12). Because of the number of forms that are transitional between Buliminella beaumonti and B. grata (illustrated in Tjalsma and Lohmann, 1983), we find it impossible to determine the taxon to which the Leg 73 forms belong. Consequently they are listed in the range charts as $B$. beaumonti-grata.

Buliminella grata Parker and Bermudez (Plate 3, Figs. $11 \mathrm{a}, \mathrm{b})$. This species is combined with Buliminella beaumonti in the range charts for Sites 523 and 524 .

Cassidulina havanensis Cushman and Bermudez. This form is found only in the upper Eocene and Oligocene sediments of Site 522 .

Chrysalogonium longicostatum Cushman and Jarvis.

Chrysalogonium tenuicostatum Cushman and Bermudez

(Plate 3, Fig. 13).

Cibicides sp. 1 (Plate 5, Figs. 5a, b). This form is found exclusively in the Paleocene sediments of Site 524; abundance is maximum in Zones NP3 to NP5. The species is similar in chamber pattern and design to $\mathrm{Ci}$ bicidoides subspiratus (Nuttall), but it has a distinctly plano-convex form, in contrast to the unequal biconvexity of $C$. subspiratus.
Cibicidoides bradyi (Trauth) (Plate 4, Figs. 1a-c) [= Truncatulina dutemplei Brady (non d'Orbigny), Truncatulina bradyi Trauth].

Cibicidoides grimsdalei (Nuttall) (Plate 4, Figs. 2a-c) [ = Cibicides grimsdalei Nuttall].

Cibicidoides havanensis (Cushman and Bermudez) (Plate 4, Figs. 3a-c) $[=$ Cibicides havanensis Cushman and Bermudez].

Cibicidoides kullenbergi (Parker). This form is present in the Oligocene down to the calcareous nannofossil zone NP23; it occurs at Sites 522 and 523.

Cibicidoides sp. aff. C. madrugaensis (Cushman and Bermudez) (Plate 4, Figs. 5a-c) [= Cibicides madrugaensis Cushman and Bermudez]. The Leg 73 forms exhibit depressed but not limbate sutures on the umbilical side and have a less angulate periphery than indicated by the type description.

Cibicidoides sp. aff. C. ungerianus (d'Orbigny) (Plate 4, Figs. 4a-c) [ = Rotalina ungeriana d'Orbigny]. Cibicidoides ungerianus resembles $C$. kullenbergi closely and may be its ancestral form. We agree with the observations of Tjalsma and Lohmann (1983) in that our specimens also lack the granular center on the spiral side as noted in the type description. This form is particularly abundant in the upper Eocene.

Cibicidoides sp. 1 (Plate 5, Figs. 1a-c). This unnamed species also occurs in the Bay of Biscay Paleogene (K. Miller, pers. comm., 1982). It may be a morphologic variant of Cibicidoides sp. cf. C. ungerianus (L. Tjalsma, pers. comm., 1982).

Clinapertina inflata Tjalsma and Lohmann (Plate 5, Figs. 2a-c). 


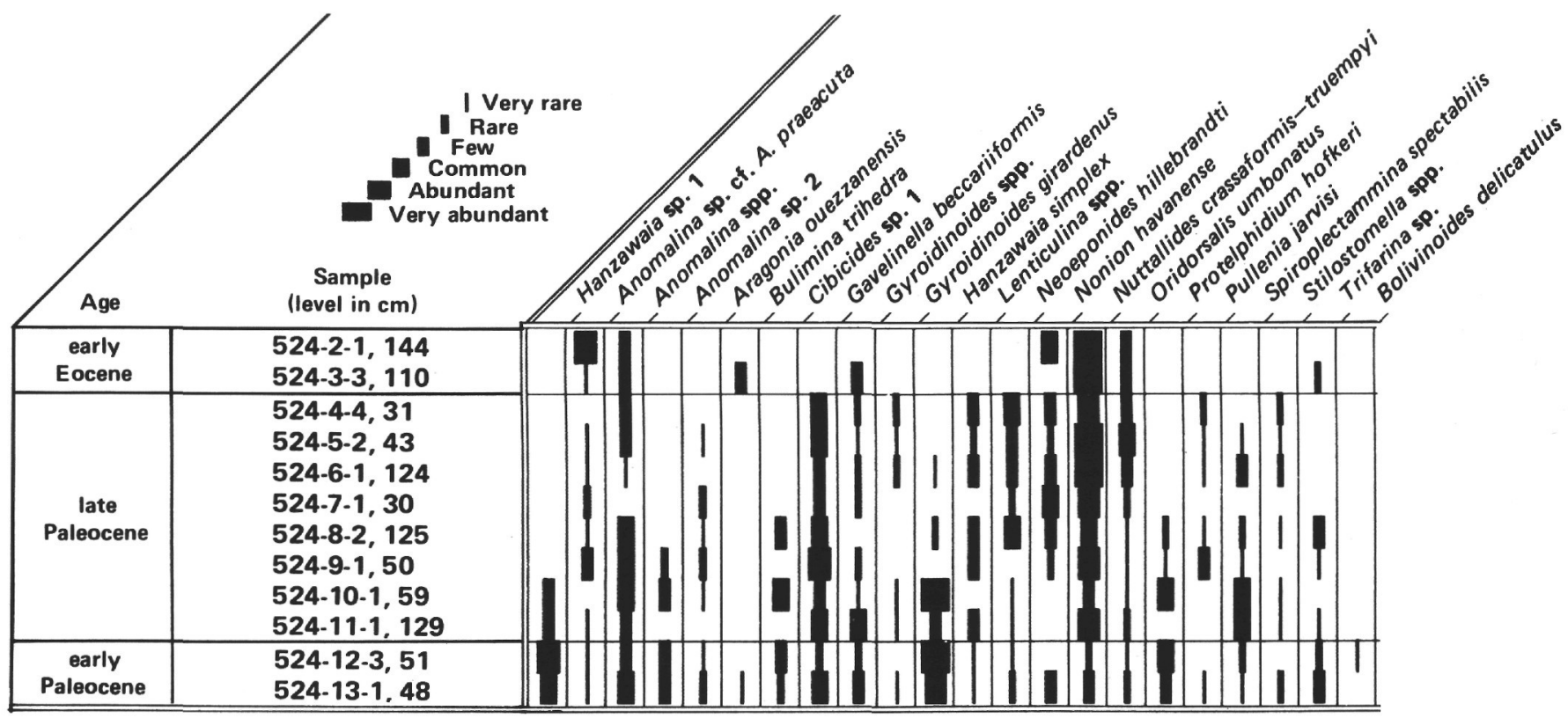

Figure 4. Paleogene benthic foraminifers in Hole 524. Abundance is defined as for Fig. 2.

Clinapertina subplanispira Tjalsma and Lohmann. Dentalina mucronata Neugeboren (Plate 5, Fig. 6). Dorothia oxycona (Reuss) [ = Gaudryina oxycona Reuss, 1860].

Dorothia trochoides (Marsson) (Plate 6, Fig. 7) [ = Gaudryina crassa Marsson var. trochoides, 1878].

Ellipsodimorphina subcompacta Liebus (Plate 6, Fig. 5).

Eponides sp. 1 (Plate 6, Figs. 1a-c). This species ranges from the middle Eocene through the Oligocene and is present at Sites 522 and 523. The degree of convexity of the spiral side is variable.

Eorupertia bermudezi Anisgard (Plate 6, Figs. 2a-c). The type illustration of this species is very poor, and a positive identification cannot be made from it. The type description is, however, consistent with the Leg 73 forms. Bermudez and Gamez (1966) illustrated a form as Eorupertia bermudezi; the Leg 73 specimens resemble it very closely.

Epistominella exigua, s.1. (Brady) (Plate 5, Figs. 3a-c, 4a-c) [ = Pulvinella exigua Brady]. Ancestral forms of this species begin to appear in the middle Eocene. Resig (1976) identified this early form as Epistominella sp. and suggested its ancestry. By the late Oligocene, clearcut examples of Epistominella exigua, s.s. occur. Both the ancestral form and E. exigua, s.s. are combined in the range charts as E. exigua, s.l.

Gaudryina pyramidata Cushman (Plate 6, Figs. 4a, b) [= Gaudryina laevigata Franke var. pyramidata Cushman]. This form is restricted to the middle Eocene.

Gavelinella beccariiformis (White) (Plate 6, Figs. 3a-c) [ = Rotalia beccariiformis White]. This form is restricted to the Paleocene, where it is one of the dominant faunal elements.

Gavelinella capitata (Guembel) [ = Rotalia capitata Guembel]. Tjalsma and Lohmann (1983) distinguished Gavelinella capitata from $G$. danica by its evolute coiling and greater number of chambers (9). We separate them on the basis of the number of chambers because evolute coiling is observed in both forms.

Gavelinella danica (Brotzen) [ = Cibicides danica Brotzen]. This form is distinguished from Gavelinella capitata by having fewer chambers (7).

Gavelinella hyphalus (Fisher) (Plate 7, Figs. 1a-c) [= Planulina dayi var. White, Anomalinoides hyphalus Fisher, 1969]. This species is very similar to Gavelinella velascoensis but can be distinguished by its less convex, involute dorsal side, its greater number of chambers, its more completely developed umbilical plug, and its smaller test (Tjalsma and Lohmann, 1983). The Leg 73 specimens do not have a pronounced umbilical plug or a significantly greater number of chambers.

Gavelinella semicribrata (Beckmann) (Plate 7, Figs. 5ac) [ = Anomalina pompilioides Galloway and Heminway var. semicribrata Beckmann].

Gavelinella velascoensis (Cushman) (Plate 7, Figs. 2a, b) [ = Anomalina velascoensis Cushman]. This form is very similar to Gavelinella hyphalus but is distinguished by its evolute, convex dorsal side and larger test.

Globocassidulina subglobosa (Brady) (Plate 6, Figs. 6a, b) [ = Cassidulina subglobosa Brady]. This form first appears in the lower Eocene and increases in abundance to a maximum in the upper Eocene and Oligocene.

Gyroidinoides girardanus (Reuss) (Plate 7, Figs. 4a-c) [= Rotalina girardana Reuss]. All Gyroidinoides with a vaulted to subconical umbilical side and curved to oblique sutures on the spiral side are included in this taxon. Rotalia soldanii (d'Orbigny) var. subangulata Plummer, Gyroidina orbicularis d'Orbigny var. obliquata Cushman and McMasters, and G. zealandica Finlay are names that have been used for var- 


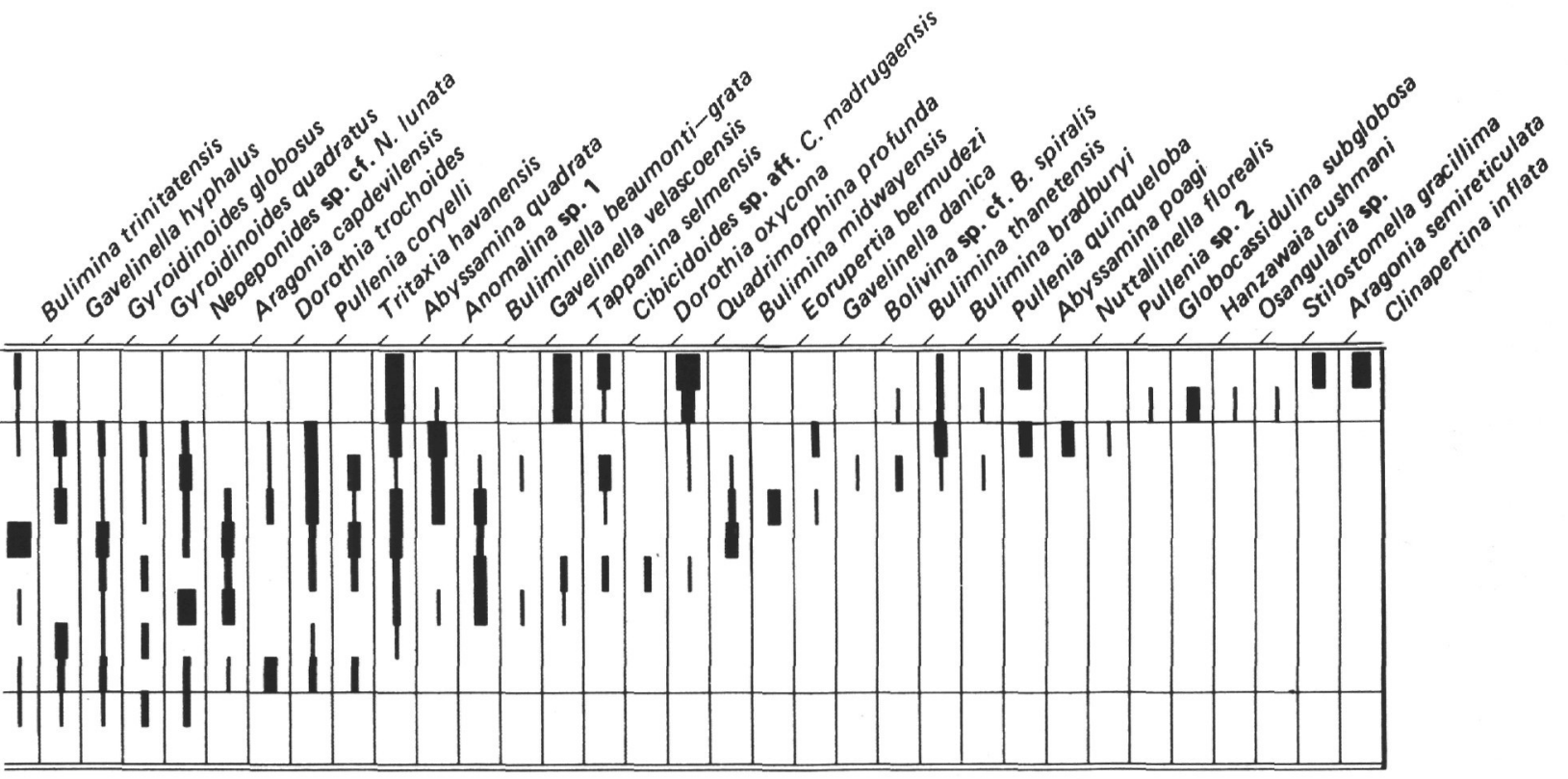

Figure 4. (Continued).

iation on this basic morphology; they are included here in the concept of Gyroidinoides girardanus.

Gyroidinoides globosus (Hagenow) [ = Nonionina globosa Hagenow, Gyroidinoides globosa (Hagenow) in Proto Decima and Bolli (1978)].

Gyroidinoides peramplus (Cushman and Stainforth) (Plate 7, Figs. 3a-c) [ = Gyroidina girardana (Reuss) var. perampla Cushman and Stainforth].

Gyroidinoides planulatus (Cushman and Renz) (Plate 8, Figs. 1a-c) [ = Gyroidina planulata Cushman and Renz]. The convexity of the spiral side is quite variable. Specimens with flattened spiral sides assume the appearance of Anomalina but lack the distinctive anomalinid aperture.

Gyroidinoides quadratus (Cushman and Church) (Plate 8, Figs. 2a-c) [ = Gyroidina quadrata Cushman and Church].

Hanzawaia cushmani (Nuttall) (Plate 8, Figs. 3a-c) [ = Cibicides cushmani Nuttall].

Hanzawaia simplex (Brotzen) (Plate 8, Figs. 5a-c) [= Cibicides simplex Brotzen]. Brotzen's description of Cibicides simplex suggests some variability. The Leg 73 forms are encompassed within that variability. The form is flat to concave on the umbilical side with a narrow periphery. This species is found only in the Paleocene sediments of Hole 524. It is the dominant species in Zones NP3 to NP5.

Hanzawaia sp. 1 (Plate 8, Figs. 4a-c). This species is similar to Hanzawaia simplex, but it has more inflated chambers and a more lobate outline. It is restricted to the Paleocene sediments of Hole 524 (NP3 to NP5).

Heronallenia sp. (Plate 9, Figs. 5a, b). This species occurs sporadically from the middle Eocene through the Oligocene.

Karreriella chapapotensis (Cole) (Plate 9, Fig. 1) [ = Textularia chapapotensis Cole].
Karreriella subglabra (Guembel) (Plate 9, Fig. 2) [= Gaudryina subglabra Guembel].

Neoeponides hillebrandti Fisher (Plate 9, Figs. 3a-c) [ = Eponides whitei Hillebrandt (non Brotzen), Neoeponides hillebrandti Fisher]. This form occurs in the Leg 73 material with a bimodal size distribution; the average size of one group is $375 \mu \mathrm{m}$, that of the other $180 \mu \mathrm{m}$.

Neoeponides sp. cf. $N$. lunata (Brotzen) (Plate 9, Figs. $6 \mathrm{a}-\mathrm{c}$ ) [ = Eponides lunata Brotzen]. The Leg $73 \mathrm{spec}-$ imens differ from Neoeponides lunata in having a small umbilical boss and less curved sutures on the umbilical side. These differences were also observed by Tjalsma and Lohmann (1983).

Nonion havanense Cushman and Bermudez (Plate 10, Figs. 1a, b). Specimens with both rounded and subacute peripheral margins are included in our concept of Nonion havanense.

Nuttallides crassaformis (Cushman and Siegfus) (Plate 9, Figs. 7a, b) $[=$ Asterigerina crassaformis Cushman and Siegfus]. Nuttallides crassaformis is not easily separated from $N$. truempyi, although $N$. crassaformis has chamberlets encircling the umbilical boss that are absent in N. truempyi. These chamberlets are often indistinct. Both forms are combined in the range charts for Sites 523 and 524.

Nuttallides truempyi (Nuttall) (Plate 9, Figs. 4a, b) [= Eponides truempyi Nuttall]. This species is tabulated with Nuttallides crassaformis in the range charts for Sites 523 and 524, because the two forms are not easily distinguished. This taxon is a major constituent of the middle Paleocene through middle Eocene fauna. In the upper Eocene it declines in abundance with the coincident increase of $N$. umboniferus.

Nuttallides umboniferus (Cushman) (Plate 9, Figs. 8a-c) [ = Pulvinulinella umbonifera Cushman]. This species makes its first appearance in the upper Eocene 
and becomes a dominant faunal element in the Oligocene.

Nuttallinella florealis (White) [ = Gyroidina florealis White].

Oridorsalis umbonatus (Reuss) (Plate 10, Figs. 3a-c) [ = Rotalina umbonata Reuss]. This species is present throughout the Paleogene at all sites.

Orthomorphina rohri (Cushman and Stainforth) (Plate 10, Fig. 4) [ = Nodogenerina rohri Cushman and Stainforth].

Osangularia sp. This very rare species occurs in the lower and middle Eocene.

Plectofrondicularia lirata Bermudez (Plate 10, Figs. 5ac). The overall appearance of the test is influenced by the number of chambers; the early portion is biserial, the later portion uniserial. The species is confined to the upper Eocene (NP20 to NP21). It reaches its maximum abundance in NP20, where it may comprise up to $70 \%$ of the fauna.

Pleurostomella alternans Schwager (Plate 11, Fig. 1).

Pleurostomella sp. cf. P. bierigi Palmer and Bermudez (Plate 11, Fig. 2). The Leg 73 forms are not as apically acute, nor do they have as many small initial chambers, as in the type description.

Pleurostomella brevis Schwager (Plate 11, Fig. 3).

Pleurostomella subcylindrica (Cushman) (Plate 11, Fig. 4) [= Nodosarella subcylindrica Cushman $]$.

Pleurostomella sp. 1 (Plate 11, Fig. 5). This very rare form is characterized by hollow pendulant extensions of the chambers that drape longitudinally down over earlier chambers. This form also occurs in the upper middle Eocene of the Southern Ocean (S. Jones, pers. comm., 1980).

Pleurostomella sp. 2 (Plate 11, Figs. 6a, b). The final chamber of this species extends three-quarters the length of the test. The form is similar to Pleurostomella alazanensis Cushman but is broader and has more inflated chambers.

Protelphidium hofkeri Haynes (Plate 10, Figs. 2a, b).

Pullenia coryelli White (Plate 12, Figs. $4 \mathrm{a}, \mathrm{b}$ ).

Pullenia eocenica Cushman and Siegfus.

Pullenia jarvisi Cushman (Plate 11, Figs. 11a, b).

Pullenia quinqueloba (Reuss) (Plate 12, Figs. 2a, b) [ = Nonionina quinqueloba Reuss]. Although the species is described as having five chambers in the final whorl, most of the Leg 73 material exhibits 5.5 chambers.

Pullenia sp. 1 (Plate 12, Figs. 1a, b). This form is slightly compressed, oval in peripheral outline, and has an aperture that extends nearly the entire width of the test. Although its aperture is reminiscent of Pullenia eocenica, it is more compressed and has a greater number of chambers.

Pullenia sp. 2 (Plate 11, Figs. 10a, b). The chamber height expands very rapidly in this Pullenia.

Pyrulina curvatura Cushman and Stainforth (Plate 11, Fig. 8). [ = Pyrulina cylindroides (Roemer) var. curvatura Cushman and Stainforth].

Pyrulina? sp. (Plate 11, Fig. 7). This species was illustrated by Beckmann (1953) as Pyrulina extensa (Cushman). However, it does not correspond to the type description of Polymorphina extensa Cushman.
Quadratobuliminella sp. (Plate 12, Figs. 5a-c). This rare form occurs only in the upper and middle Eocene. Because of the quadrate outline of the final whorl of chambers and the grooves radiating from the aperture, it appears to be related to Quadratobuliminella pyramidalis (de Klasz) as illustrated by Tjalsma and Lohmann (1983); however, it does not have the more elongate pyramid-shaped test of $Q$. pyramidalis.

Quadrimorphina profunda Schnitker and Tjalsma (Plate 12, Figs. 3a-c).

Siphogenerina? transversa Cushman (Plate 11, Fig. 9) [ = Siphogenerina raphanus (Parker and Jones) var. transversus Cushman]. The indistinct nature of the early chambers precludes a positive generic assignment for this form.

Siphotextularia heterostoma (Fornasini) (Plate 13, Fig. 6) $[=$ Textilaria heterostoma Fornasisi $]$. Tjalsma and Lohmann (1983) refer to this form as Karreriella sp. cf. $K$. cubensis Cushman and Bermudez. Forms from the Paleogene of the Nazca Plate are identified as Siphotextularia heterostoma by Resig (1976).

Spiroloculina sp. This form is rare in the middle Eocene through Oligocene.

Spiroplectammina spectabilis (Grzybowski) (Plate 13, Fig. 5) [ = Spiroplecta spectabilis Grzybowski].

Stetsonia sp. (Plate 12, Figs. 6a-c). The central area of each side of this species is covered by a low clear boss, through which earlier chambers are sometimes visible.

Stilostomella aculeata (Cushman and Renz) (Plate 13, Fig. 2) [= Ellipsonodosaria nuttalli Cushman and Jarvis var. aculeata Cushman and Renz].

Stilostomella gracillima (Cushman and Jarvis) $[=$ Ellipsonodosaria nuttalli Cushman and Jarvis var. gracillima Cushman and Jarvis].

Stilostomella subspinosa (Cushman) (Plate 13, Fig. 3) [ = Ellipsonodosaria subspinosa Cushman].

Tappanina selmensis (Cushman) (Plate 13, Fig. 7) [ = Bolivinita selmensis Cushman]. This form is found in the Paleocene and lower Eocene.

Trifarina sp. (Plate 13, Fig. 9). This form is present in the Paleocene and Eocene.

Triloculina sp. This rare form occurs only in the Oligocene at Sites 522 and $\mathbf{5 2 3 .}$

Tritaxia havanensis (Cushman and Bermudez) (Plate 13, Figs. 4a-b) [ = Clavulinoides havanensis Cushman and Bermudez].

Turrilina robertsi (Howe and Ellis) (Plate 13, Figs. 8a, b) [ = Bulimina robertsi Howe and Ellis].

Vulvulina spinosa Cushman (Plate 13, Fig. 1). We agree with Tjalsma and Lohmann (1983) that Vulvulina jarvisi is a synonym of $V$. spinosa.

\section{Paleontological Sources}

The authors consulted the following sources in constructing the taxonomy.

Beckmann, J. P., 1953. Die Foraminiferen der Oceanic Formation (Eocaen-Oligocaen) von Barbados, K1. Antillen. Ecol. Geol. Helv., 46:301-412.

Bermudez, P. J., 1949. Tertiary smaller foraminifera of the Dominican Republic. Spec. Publ. Cushman Lab. Foraminiferal. Res., 25: 1-322. 
Bermudez, P. J., and Gamez, H. A., 1966. Estudio paleontológico de una sección del Eoceno. Mem. Soc. Cienc. Nat. La Salle, 26: 205-259.

Cushman, J. A., 1925. Some new foraminifera from the Velasco Shale of Mexico. Contrib. Cushman Lab. Foraminiferal Res., 1: 18-23.

Cushman, J. A., and Jarvis, P. W., 1932. Upper Cretaceous foraminifera from Trinidad. Proc. U.S. Natl. Mus., 80(14):1-60.

Cushman, J. A., and Renz, H. H., 1947. The foraminiferal fauna of the Oligocene Ste. Croix Formation of Trinidad, B. W. I. Spec. Publ. Cushman Lab. Foraminiferal. Res., 22:1-46.

Douglas, R. G., 1973. Benthonic foraminiferal biostratigraphy in the central North Pacific, Leg 17, Deep Sea Drilling Project. In Winterer, E. L., Ewing, J. I., et al., Init. Repts. DSDP, 17: Washington (U.S. Govt. Printing Office), 607-671.

Mallory, V. S., 1959. Lower Tertiary biostratigraphy of the California Coast Ranges. Stud. Geol. Tulsa Okla., pp. 1-416.

Nuttall, W. L. F., 1932. Lower Oligocene foraminifera from Mexico. J. Paleontol., 6:3-45.

Schnitker, D., 1979. Cenozoic deep water benthic foraminifers, Bay of Biscay. In Montadert, L., Roberts, D. G., et al., Init. Repts. DSDP, 48: Washington (U.S. Govt. Printing Office), 377-413.

White, M. P., 1928. Some index foraminifera of the Tampico Embayment area of Mexico. J. Paleontol., 2:177-215.

\section{ACKNOWLEDGMENTS}

We thank Charles Pflum and Sherwood Wise, Jr. for critically reviewing the manuscript, and we especially thank Leonard Tjalsma for valuable taxonomic discussions. Ralph Hockett is gratefully acknowledged for his preparation of the SEM illustrations.

\section{REFERENCES}

Beckmann, J. P., Bolli, H. M., Perch-Nielsen, K., Proto Decima, F., Saunders, J. B., and Toumarkine, M., 1981. Major calcareous nannofossil and foraminiferal events between the middle Eocene and early Miocene. Palaeogeogr., Palaeoclimatol., Palaeoecol., 36:155-190.

Berger, W. H., and von Rad, U., 1972. Cretaceous and Cenozoic sediments from the Atlantic Ocean. In Hayes, D. E., Pimm, A. C., et al., Init. Repts. DSDP, 14: Washington (U.S. Govt. Printing Office), 787-954.

Corliss, B. H., 1981. Deep-sea benthonic foraminiferal faunal turnover near the Eocene-Oligocene boundary. Mar. Micropaleontol., 6:367-384.

Ellis, B. F., and Messina, Angelina, 1940 (supplements, post-1940). Catalogue of Foraminifera: New York (Am. Mus. Nat. Hist.).

Miller, K. G., in press. Late Paleogene (Eocene to Oligocene) paleoceanography of the deep Bay of Biscay: benthic foraminiferal evidence. Mar. Micropaleontol.

Proto Decima, F., and Bolli, H. M., 1978. Southeast Atlantic DSDP Leg 40 Paleogene benthic foraminifers. In Bolli, H. M., Ryan, W. B. F., et al., Init. Repts. DSDP, 40: Washington (U.S. Govt. Printing Office), 783-809.

Resig, J. M., 1976. Benthic foraminiferal stratigraphy, eastern margin, Nazca Plate. In Yeats, R. S., Hart, S. R., et al., Init. Repts. DSDP, 34: Washington (U.S. Govt. Printing Office), 743-759.

Schnitker, D., and Tjalsma, R. C., 1980. New genera and species of benthic foraminifers from Paleocene and Eocene deep-water deposits. J. Foraminiferal Res., 10:235-241.

Tjalsma, R. C. and Lohmann, G. P., 1983. Paleocene-Eocene bathyal and abyssal benthic foraminifera from the Atlantic Ocean. Micropaleontology, Spec. Publ. 4.

Date of Initial Receipt: August 13, 1982 


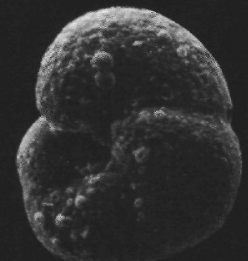

$1 \mathrm{a}$

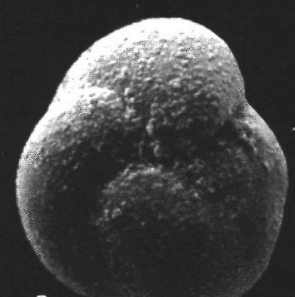

2a

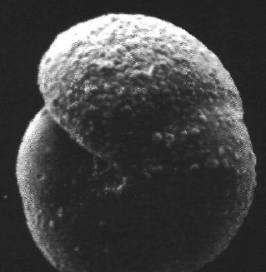

3a

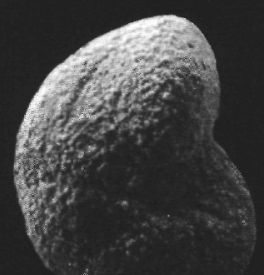

$4 a$

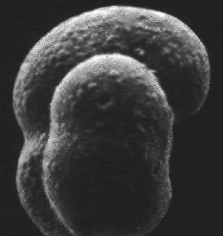

$1 b$

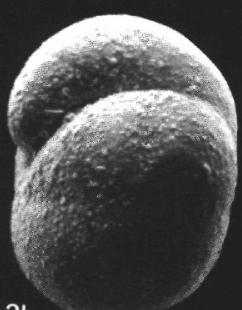

$2 b$

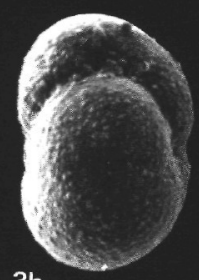

$3 b$

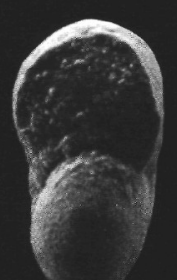

$4 b$

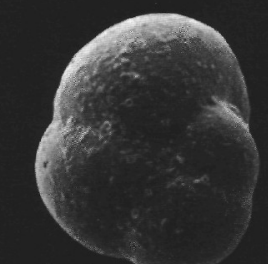

$1 c$

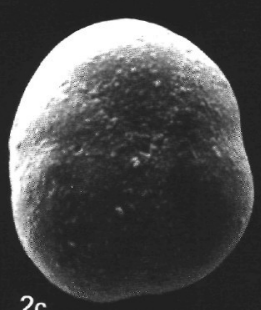

$5 a$

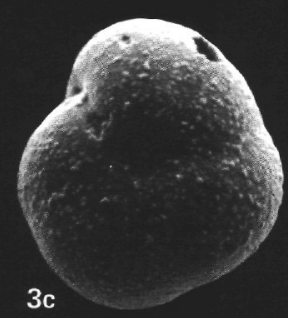

$5 b$

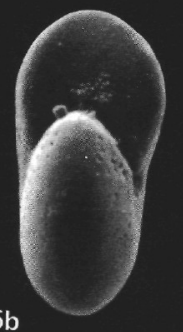

$5 c$

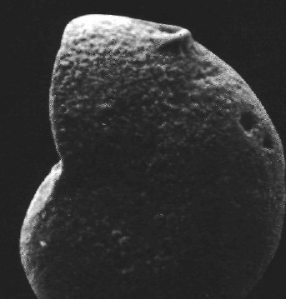

$4 c$
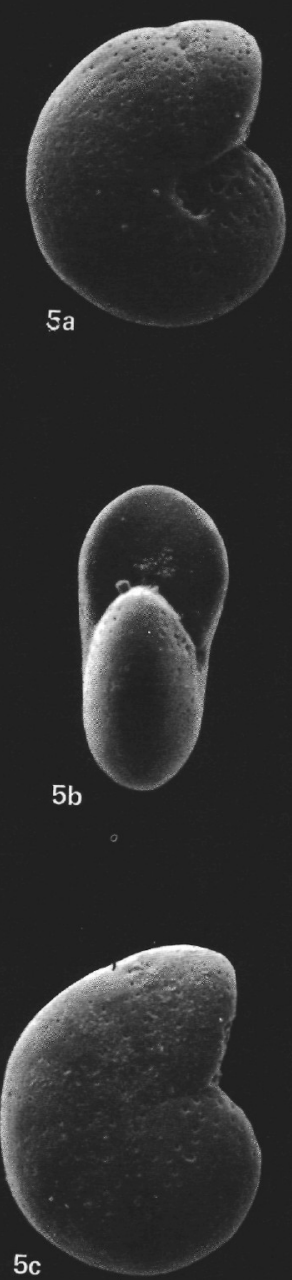

Plate 1. Benthic foraminiferal species. 1. Abyssamina incisa. a. Umbilical view, Core 522-37, $184 \mu \mathrm{m}$. b. Edge view, Core 523-31, 186 $\mu \mathrm{m}$. c. Spiral view, Core 523-28, $181 \mu \mathrm{m}$. 2. Abyssamina poagi. a. Umbilical view, Core 523-42, $246 \mu \mathrm{m}$. b. Edge view, Core $523-47,253 \mu \mathrm{m}$. c. Spiral view, Core 523-45, $234 \mu \mathrm{m}$. 3. Abyssamina quadrata. a. Umbilical view, Core 524-3, $190 \mu \mathrm{m}$. b. Edge view, Core 524-3, 219 $\mu \mathrm{m}$. c. Spiral view, Core 524-5, $186 \mu \mathrm{m}$. 4. Anomalina sp. 2. a. Umbilical view, Core 524-12, $224 \mu \mathrm{m}$. b. Edge view, Core 524-12, $208 \mu \mathrm{m}$. c. Spiral view, Core 524-12, $251 \mu \mathrm{m}$. 5. Anomalina sp. cf. A. spissiformis. a. Umbilical view, Core 522-37, $373 \mu \mathrm{m}$. b. Edge view, Core 522-37, 373 $\mu \mathrm{m}$. c. Spiral view, Core 522-38, $387 \mu \mathrm{m}$. 


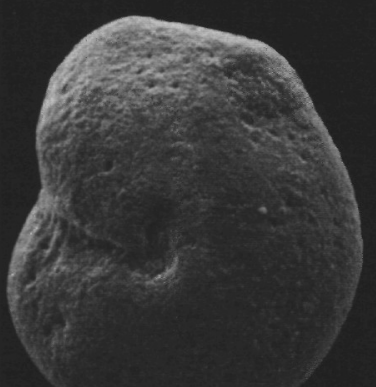

$1 \mathrm{a}$

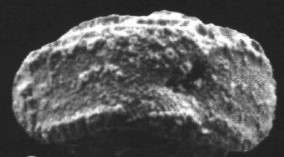

2a

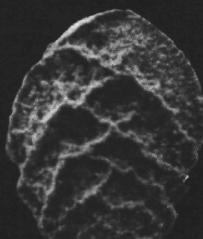

$2 b$

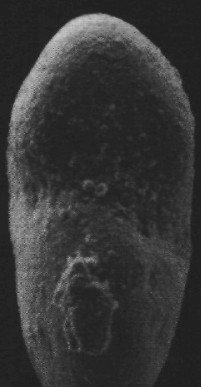

$1 b$

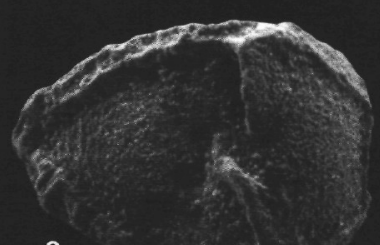

$3 a$

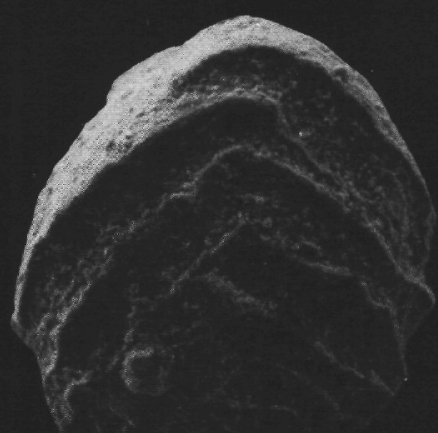

$3 \mathrm{~b}$
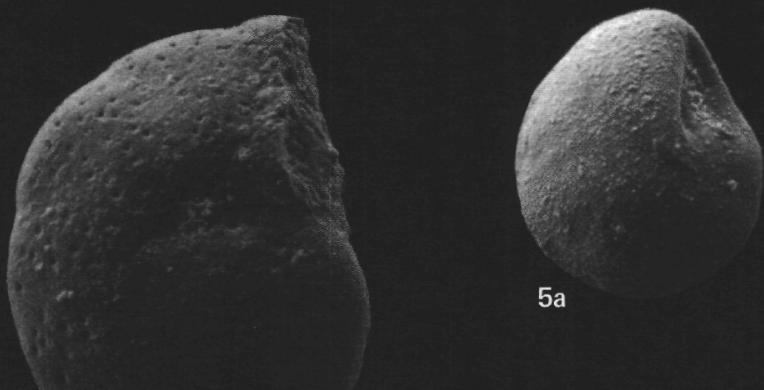

$5 a$

1c

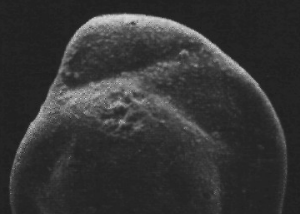

$5 b$
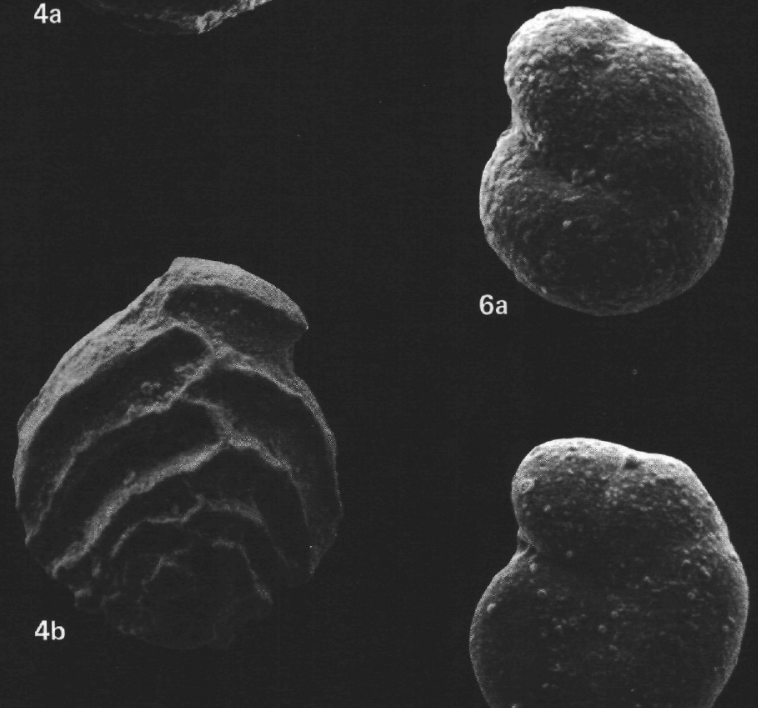

$6 b$

Plate 2. Benthic foraminiferal species. 1. Anomalina sp. cf. A. praeacuta. a. Umbilical view, Core 524-4, $301 \mu \mathrm{m}$. b. Edge view, Core 524-8, 312 $\mu \mathrm{m}$. c. Spiral view, Core $524-9,251 \mu \mathrm{m}$. 2. Aragonia semireticulata. a. Apertural view. Core 523-41, 211 $\mu \mathrm{m}$. b. Core 523-44, 290 $\mu \mathrm{m}$. 3. Aragonia ouezzanensis. a. Apertural view. Core 524-12, $315 \mu \mathrm{m}$. b. Core 524-13, $368 \mu \mathrm{m}$. 4. Aragonia capdevilensis. a. Apertural $\mu \mathrm{m}$. 3. Aragonia ouezzanensis. a. Apertural view. Core $524-12,315 \mu \mathrm{m}$. b. Core $524-13,368 \mu \mathrm{m}$. 4 . Are $523-46,326 \mu \mathrm{m}$. b. Spiral view, Core 523-44, $326 \mu \mathrm{m}$. 6. Anomalina sp. 1. a. Umbilical view, Core 524-5, $227 \mu \mathrm{m}$. b. Spiral view, Core 524-8, $237 \mu \mathrm{m}$. 


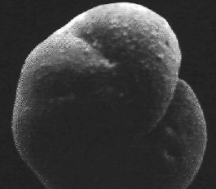

1 a

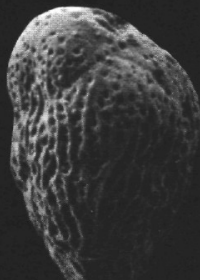

8

5

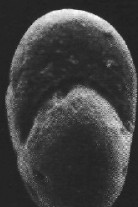

$1 \mathrm{~b}$

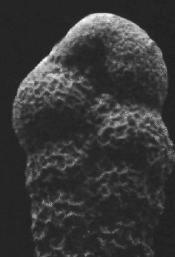

2

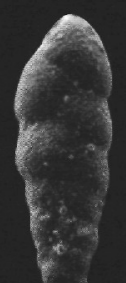

3

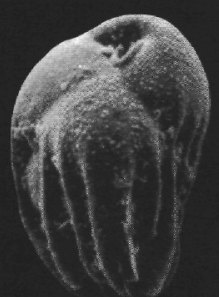

$4 a$

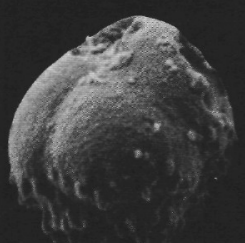

7

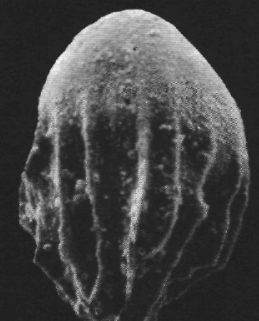

$4 b$

b

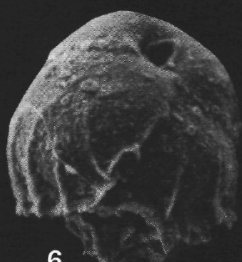

6

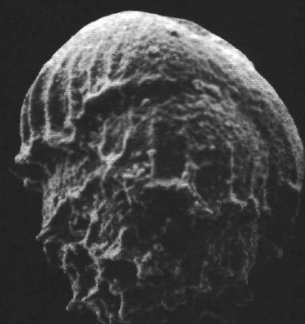

9

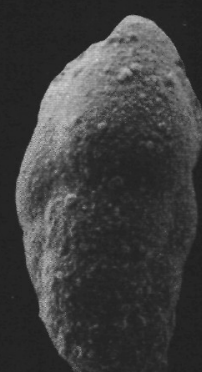

10

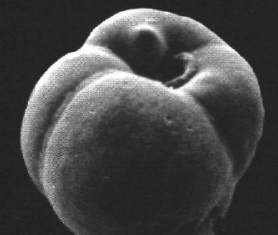

$11 a$

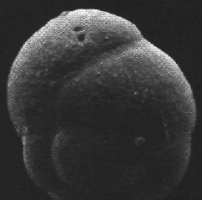

$11 b$

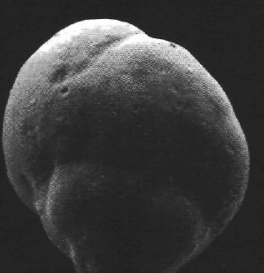

12

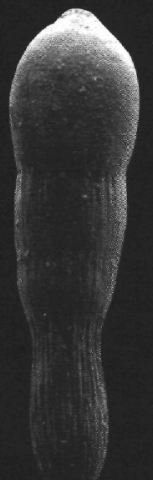

13

Plate 3. Benthic foraminiferal species. 1. Astrononion pusillum. a. Core 522-34, $227 \mu \mathrm{m}$. b. Edge view, Core 522-34, 238 $\mu \mathrm{m} .2$. Bolivina huneri. Core 522-34, $422 \mu \mathrm{m}$. 3. Bolivina sp. cf. B. spiralis. Core 523-28, $374 \mu \mathrm{m}$. 4. Bulimina alazanensis. a. Core 522-36, 200 $\mu \mathrm{m}$. b. Core $522-38,245 \mu \mathrm{m}$. 5. Bulimina bradburyi. Core 524-3, $290 \mu \mathrm{m}$. 6. Bulimina impendens. Core 523-35, $176 \mu \mathrm{m}$. 7. Bulimina midwayensis. Core $524-2,195 \mu \mathrm{m}$. 8. Bulimina semicostata. Core 523-36, $368 \mu \mathrm{m}$. 9. Bulimina trinitatensis. Core 523-46, 387 $\mu \mathrm{m}$. 10. Bulimina thanetensis. Core 524-5, $288 \mu \mathrm{m}$. 11. Buliminella grata. a. Apertural view, Core 523-30, $178 \mu \mathrm{m}$. b. Core 522-22, $208 \mu \mathrm{m}$. 12. Buliminella beaumonti. Core 523-14, $192 \mu \mathrm{m}$. 13. Chrysalogonium tenuicostatum. Core $522-34,1056 \mu \mathrm{m}$. 


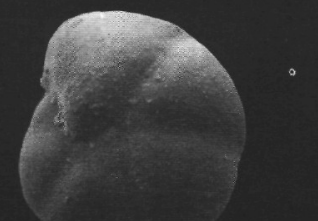

1a

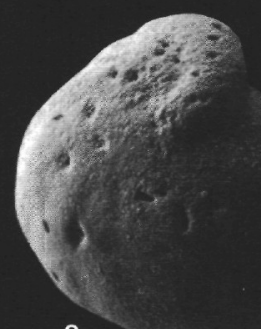

$2 \mathrm{a}$

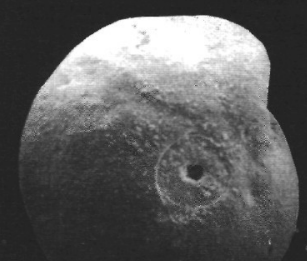

$3 a$

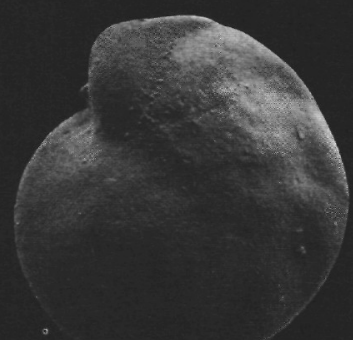

$4 a$

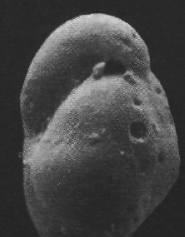

$1 b$

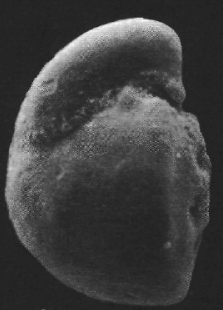

$2 b_{\circ}$

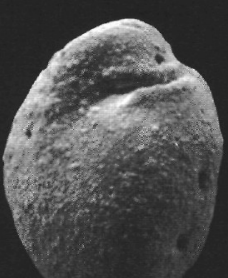

$3 \mathrm{~b}$

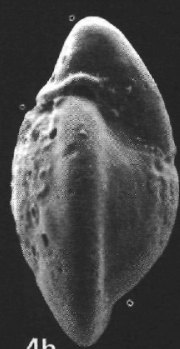

$4 b$
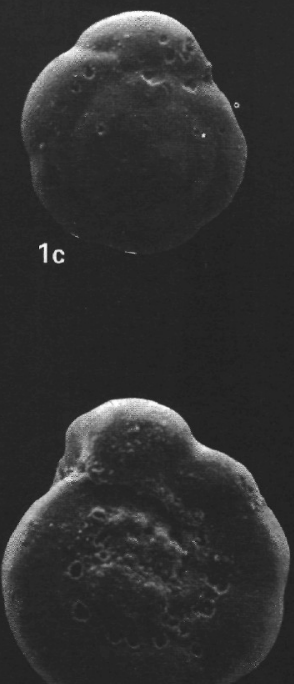

$2 c$

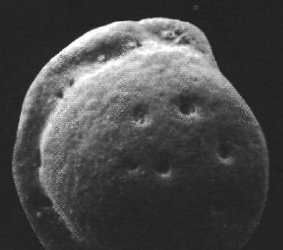

$3 c$

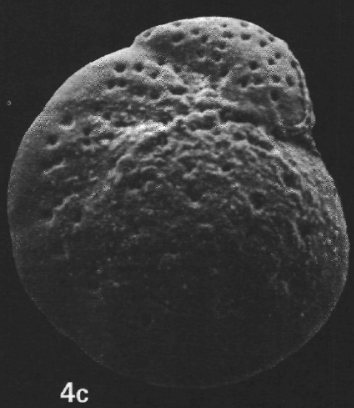

$5 a$

$5 b$

s

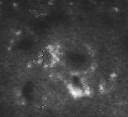

$5 c$

Plate 4. Benthic foraminiferal species. 1. Cibicidoides bradyi. a. Umbilical view, Core 522-34, $277 \mu \mathrm{m}$. b. Edge view, Core 522-33, 245 $\mu \mathrm{m}$. c. Spiral view, Core $522-33,210 \mu \mathrm{m}$. 2. Cibicidoides grimsdalei. a. Umbilical view, Core $522-21,765 \mu \mathrm{m}$. b. Edge view, Core $523-43,240 \mu \mathrm{m}$. c. Spiral view, Core 523-42, $261 \mu \mathrm{m}$. 3. Cibicidoides havanensis. a. Umbilical view, Core 522-38, $509 \mu \mathrm{m}$. b. Edge view, Core 522-38, 349 $\mu \mathrm{m}$. c. Spiral view, Core 523-35, $446 \mu \mathrm{m}$. 4. Cibicidoides sp. aff. C. ungerianus. a. Umbilical view, Core 522-37, 298 $\mu \mathrm{m}$. b. Edge view, Core 522-37, $278 \mu \mathrm{m}$. c. Spiral view, Core 522-37, $320 \mu \mathrm{m}$. 5. Cibicidoides sp. aff. C. madrugaensis. a. Umbilical view, Core 524-8, 584 $\mu \mathrm{m}$. b. Edge view, Core 524-5, $624 \mu \mathrm{m}$. c. Spiral view, Core 524-8, $584 \mu \mathrm{m}$. 


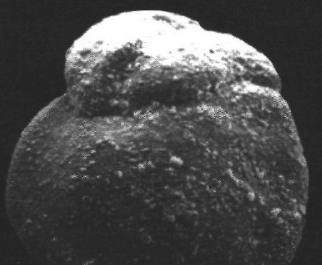

1a

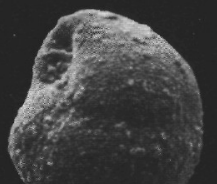

$3 a$

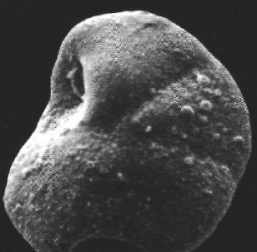

$4 \mathrm{a}$

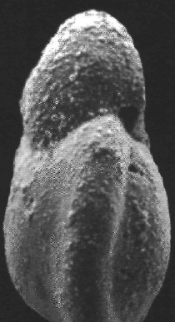

1b

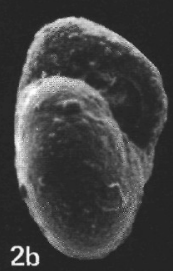

$2 b$

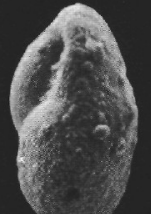

$3 \mathrm{~b}$

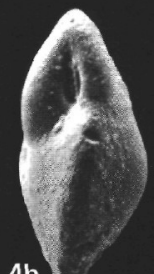

$4 b$

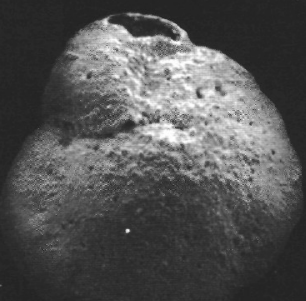

$1 \mathrm{c}$
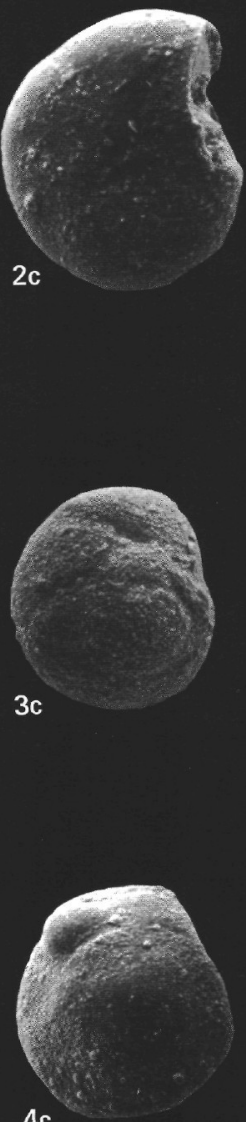

$4 c$
$5 b$

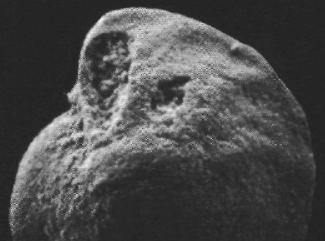

$5 a$
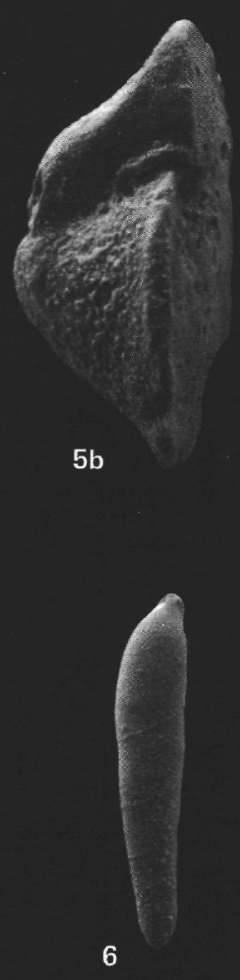

Plate 5. Benthic foraminiferal species. 1. Cibicidoides sp. 1. a. Umbilical view, Core 522-36, $285 \mu \mathrm{m}$. b. Edge view, Core 522-36, 291 $\mu \mathrm{m}$. c. Spiral view, Core 522-37, $280 \mu \mathrm{m}$. 2. Clinapertina inflata. a. Umbilical view, Core 524-2, $235 \mu \mathrm{m}$. b. Edge view, Core 524-2, 205 $\mu \mathrm{m}$. c. Spiral view, Core 524-2, $240 \mu \mathrm{m}$. 3. Epistominella exigua, s.1. a. Umbilical view, Core 522-31, $179 \mu \mathrm{m}$. b. Edge view, Core 522-31, $171 \mu \mathrm{m}$. c. Spiral view, Core 522-31, $184 \mu \mathrm{m}$. 4. Epistominella exigua, s.s. a. Umbilical view, Core 522-31, $224 \mu \mathrm{m}$. b. Edge view, Core 522-31, 218 $\mu \mathrm{m}$. c. Spiral view, Core 522-31, $214 \mu \mathrm{m}$. 5. Cibicides sp. 1. a. Umbilical view, Core 524-12, $253 \mu \mathrm{m}$. b. Edge view, Core 524-12, 253 $\mu \mathrm{m}$. 6. Dentalina mucronata. Core 522-34, $578 \mu \mathrm{m}$. 


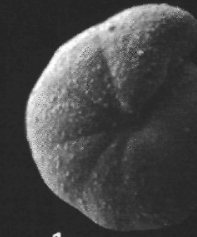

1 a

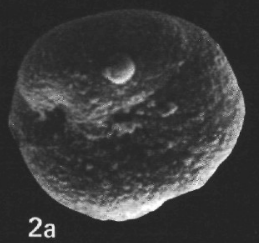

$2 \mathrm{a}$

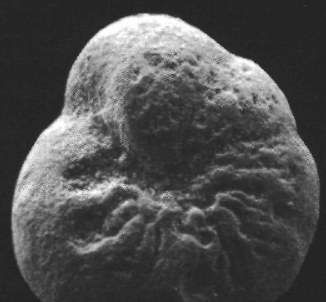

$3 \mathrm{a}$

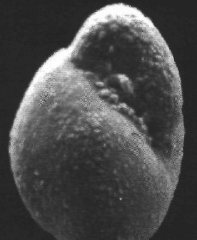

$1 b$

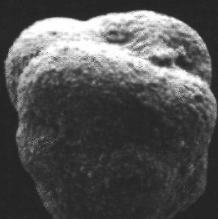

$2 b$

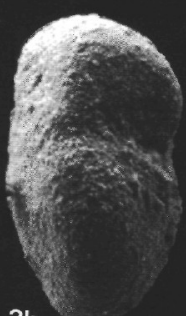

$3 b$

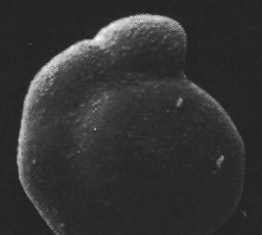

1c
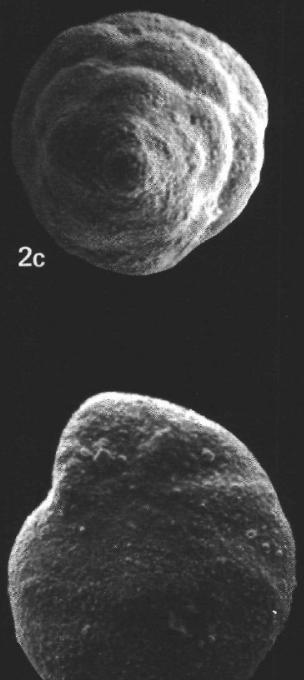

$3 \mathrm{c}$

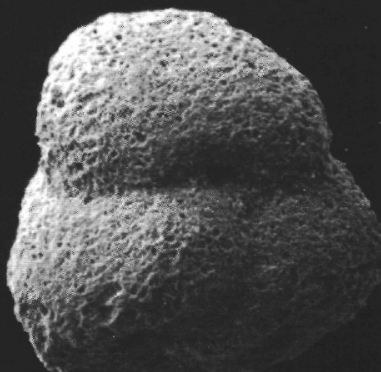

$4 b$
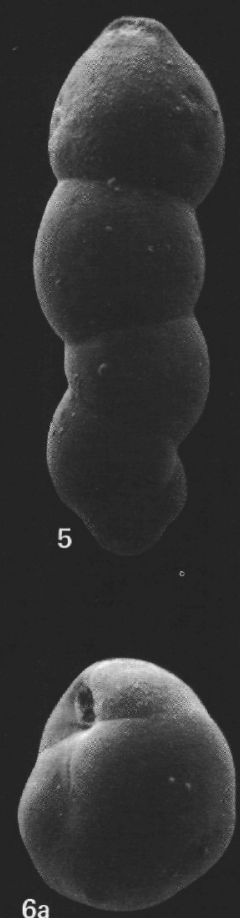

$6 \mathrm{~b}$
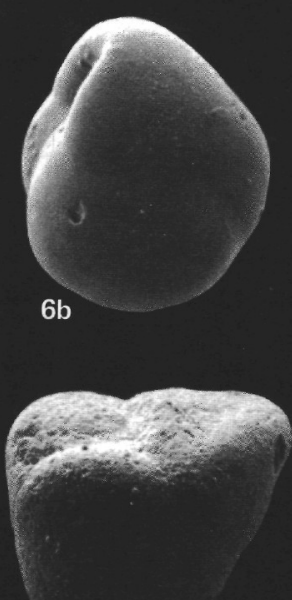

7

Plate 6. Benthic foraminiferal species. 1. Eponides sp. 1. a. Umbilical view, Core 522-34, $181 \mu \mathrm{m}$. b. Edge view, Core 522-34, $163 \mu \mathrm{m}$. c. Spiral view, Core 522-34, $192 \mu \mathrm{m}$. 2. Eorupertia bermudezi. a. Umbilical view, Core 524-6, $168 \mu \mathrm{m}$. b. Core 524-6, $144 \mu \mathrm{m}$. c. Spiral view, Core 524-6, $184 \mu \mathrm{m}$. 3. Gavelinella beccariiformis. a. Umbilical view, Core 524-9, $499 \mu \mathrm{m}$. b. Edge view, Core 524-10, $410 \mu \mathrm{m}$. c. Spiral view, Core 524-10, $432 \mu \mathrm{m}$. 4. Gaudryina pyramidata. a. Core 523-36, $832 \mu \mathrm{m}$. b. Apertural view, Core 523-36, $440 \mu \mathrm{m}$. 5. Ellipsodimorphina subcompacta. Core 523-44, $710 \mu \mathrm{m}$. 6. Globocassidulina subglobosa. a. Core 522-31, $322 \mu \mathrm{m}$. b. Core 522-31, $261 \mu \mathrm{m}$. 7. Dorothia trochoides. Core 524-5, $424 \mu \mathrm{m}$. 


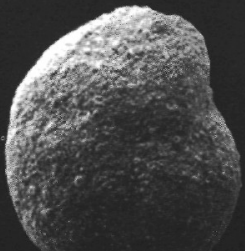

1a

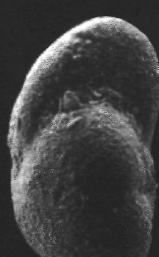

$1 b$

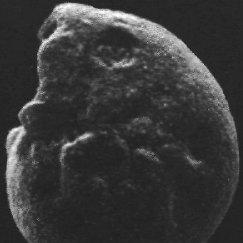

1c

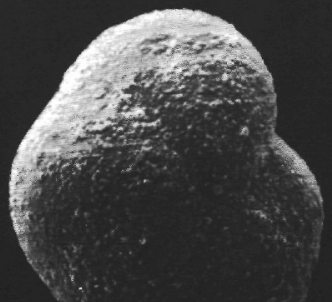

$5 a$

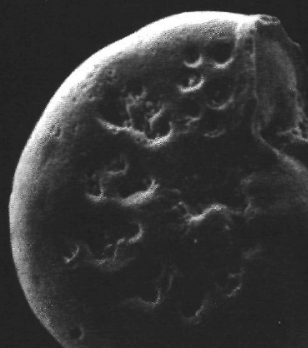

$2 b$
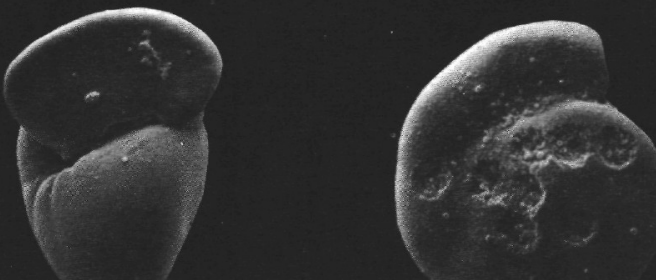

$3 c$

$4 b$

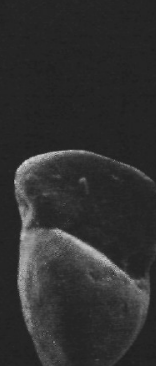

$3 b$

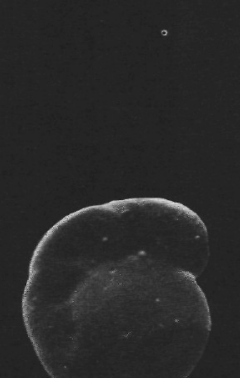

$4 c$

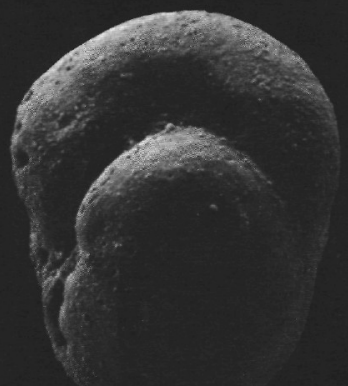

$5 b$

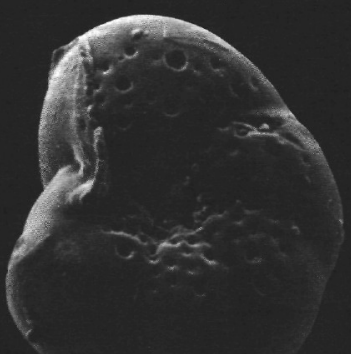

$5 c$

Plate 7. Benthic foraminiferal species. 1. Gavelinella hyphalus. a. Spiral view, Core 524-11, $258 \mu \mathrm{m}$. b. Edge view, Core 524-11, 259 $\mu \mathrm{m}$. c. Umbilical view, Core 524-6, $266 \mu \mathrm{m}$. 2. Gavelinella velascoensis. a. Edge view, Core 524-5, $374 \mu \mathrm{m}$. b. Umbilical view, Core 524-9, $304 \mu \mathrm{m}$. 3. Gyroidinoides peramplus. a. Umbilical view, Core 522-31, $376 \mu \mathrm{m}$. b. Edge view, Core 522-29, $336 \mu \mathrm{m}$. c. Spiral view, Core 522-29, $326 \mu \mathrm{m}$. 4 . Gyroidinoides girardanus. a. Umbilical view, Core 523-38, $288 \mu \mathrm{m}$. b. Edge view, Core 523-38, $246 \mu \mathrm{m}$. c. Spiral view, Core 523-37, 242 $\mu \mathrm{m}$. 5. Gavelinella semicribrata. a. Spiral view, Core 522-17, $238 \mu \mathrm{m}$. b. Edge view, Core 522-17, $333 \mu \mathrm{m}$. c. Umbilical view, Core 522-36, $318 \mu \mathrm{m}$. 


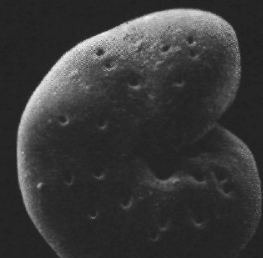

1a

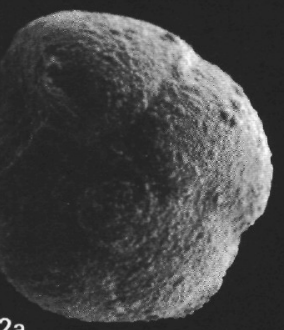

$2 \mathrm{a}$

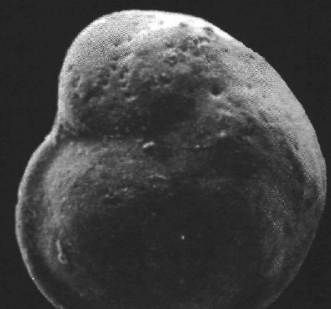

$3 a$

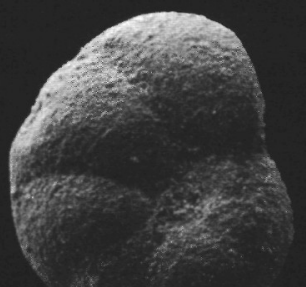

$4 a$
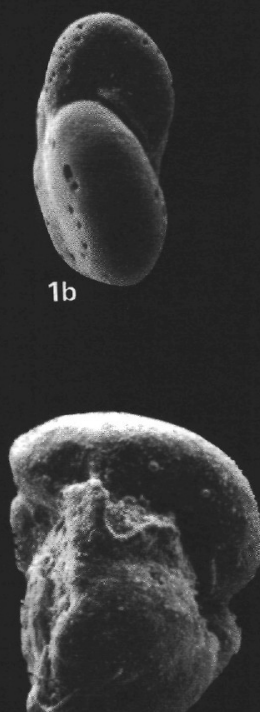

$2 b$

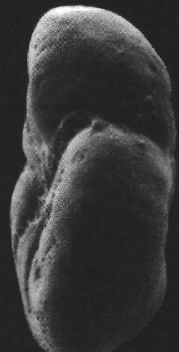

$3 b$

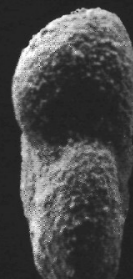

$4 \mathrm{~b}$

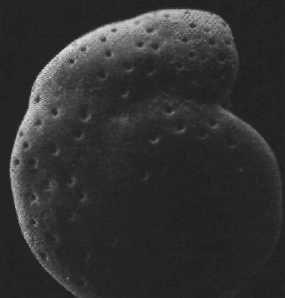

$1 c$

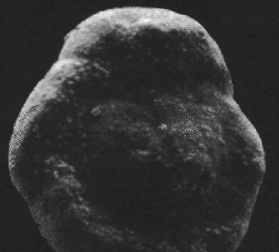

2c

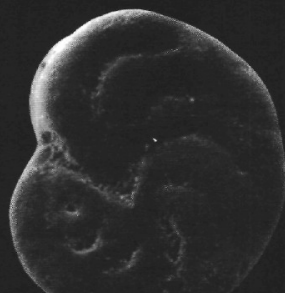

$3 c$

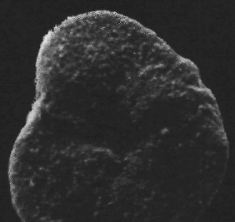

$4 c$

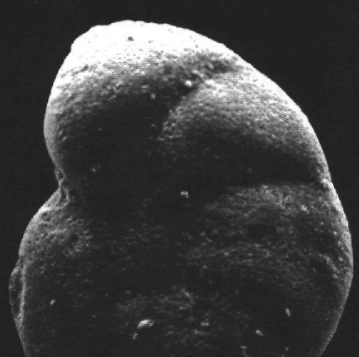

$5 a$

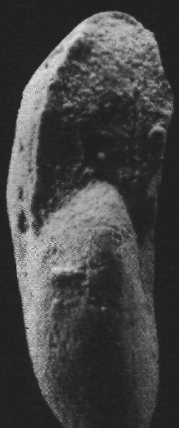

$5 b$

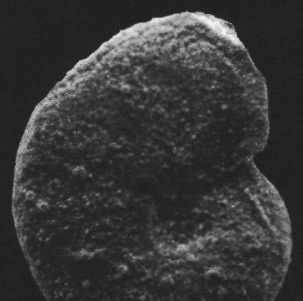

$5 c$

Plate 8. 1. Gyroidinoides planulatus. a. Umbilical view, Core 523-28, $274 \mu \mathrm{m}$. b. Edge view, Core 523-28, $286 \mu \mathrm{m}$. c. Spiral view, Core 522-38, $342 \mu \mathrm{m}$. 2. Gyroidinoides quadratus. a. Umbilical view, Core 524-4, $237 \mu \mathrm{m}$. b. Edge view, Core 524-4, 240 $\mu \mathrm{m}$. c. Spiral view, Core 524-10, $192 \mu \mathrm{m}$. 3. Hanzawaia cushmani. a. Umbilical view, Core 523-48, $280 \mu \mathrm{m}$. b. Edge view, Core 522-37, $797 \mu \mathrm{m}$. c. Spiral view, Core 523-42, 414 $\mu \mathrm{m}$. 4. Hanzawaia sp. 1, a. Umbilical view, Core 524-13, $488 \mu \mathrm{m}$. b. Edge view, Core 524-13, $440 \mu \mathrm{m}$. c. Spiral view, Core 524-13, 392 $\mu \mathrm{m}$. 5. Hanzawaia simplex. a. Umbilical view, Core 524-12, $408 \mu \mathrm{m}$. b. Edge view, Core 524-12, $325 \mu \mathrm{m}$. c. Spiral view, Core 524-12, $240 \mu \mathrm{m}$. 

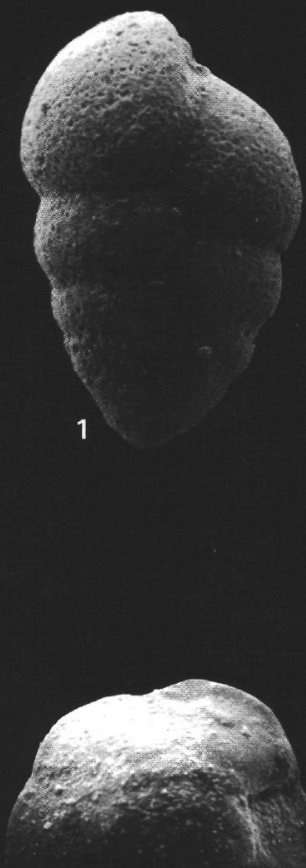

$4 a$

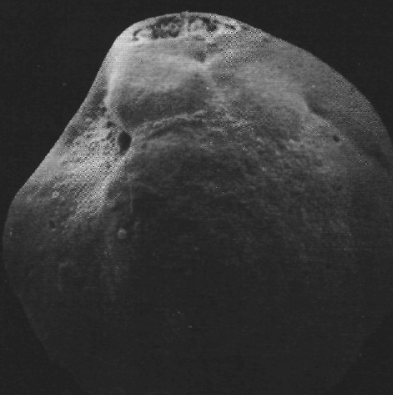

$7 a$
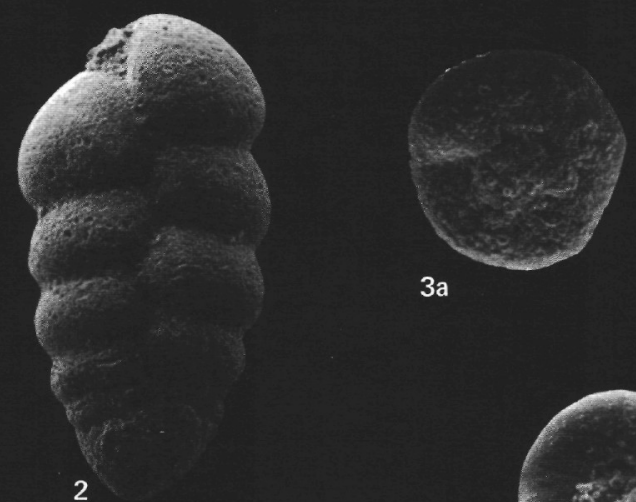

3a

$3 b$

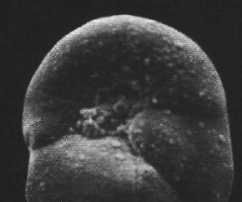

$5 a$

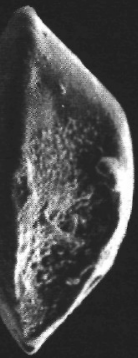

$4 b$

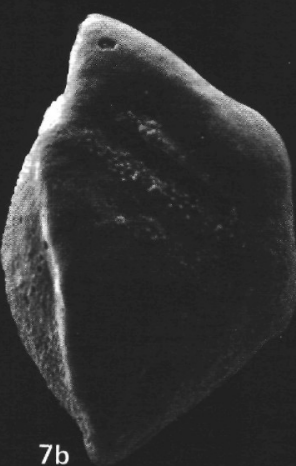

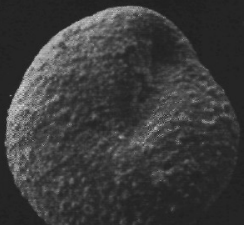

$6 a$

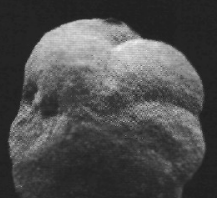

$8 a$

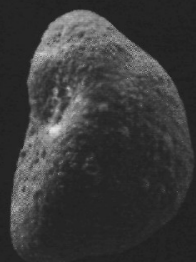

$3 c$

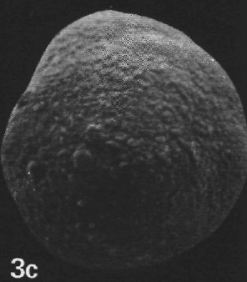

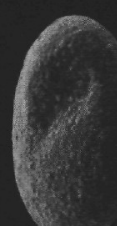

$6 b$

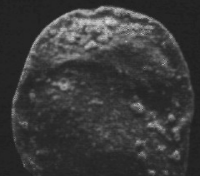

$5 b$

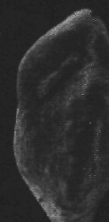

$8 b$

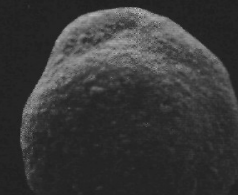

$6 c$

Plate 9. Benthic foraminiferal species. 1. Karreriella chapapotensis. Core 522-36, $563 \mu \mathrm{m}$. 2. Karreriella subglabra. Core 523-14, 624 $\mu \mathrm{m}$. 3. Neoeponides hillebrandti. a. Umbilical view, Core 524-4, $160 \mu \mathrm{m}$. b. Edge view, Core 524-4, $181 \mu \mathrm{m}$. c. Spiral view, Core 524-4, $200 \mu \mathrm{m}$. 4. Nuttallides truempyi. a. Umbilical view, Core 6-1, $320 \mu \mathrm{m}$. b. Edge view, Core 6-1, $330 \mu \mathrm{m}$. 5. Heronallenia sp. a. Umbilical view, Core 522-19, $253 \mu \mathrm{m}$. b. Spiral view, Core 522-27, $219 \mu \mathrm{m}$. 6. Neoeponides sp. cf. $N$. lunata. a. Umbilical view, Core 524-4, 181 $\mu \mathrm{m}$. b. Edge view, Core 524-4, $176 \mu \mathrm{m}$. c. Spiral view, Core 524-5, $178 \mu \mathrm{m}$. 7. Nuttallides crassaformis. a. Umbilical view, Core 523-36, 347 $\mu \mathrm{m}$. b. Edge view, Core $523-34,352 \mu \mathrm{m}$. 8. Nuttallides umboniferus. a. Umbilical view, Core 522-31, $224 \mu \mathrm{m}$. b. Edge view, Core 522-31, $246 \mu \mathrm{m}$. c. Spiral view, Core $522-29,254 \mu \mathrm{m}$ 


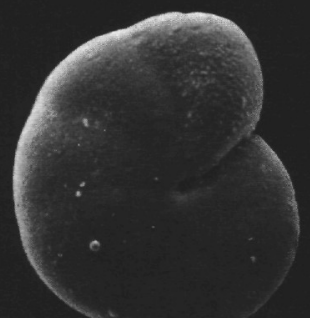

1a

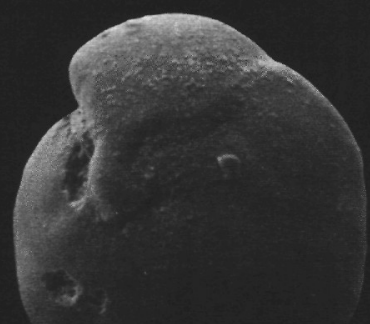

3a
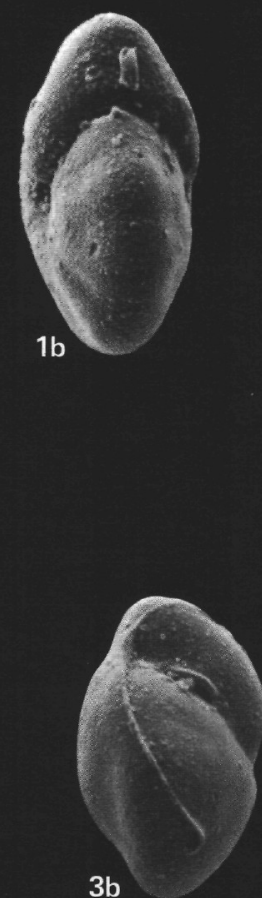

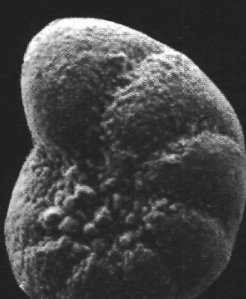

$2 \mathrm{a}$

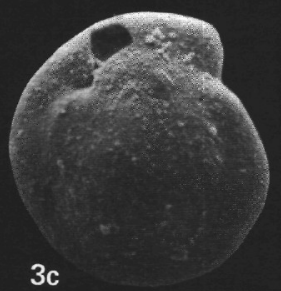

$3 \mathrm{c}$

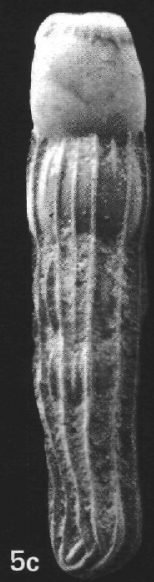

Plate 10. Benthic foraminiferal species. 1. Nonion havanense. a. Core 522-37, $293 \mu \mathrm{m}$. b. Edge view, Core 522-37, $306 \mu \mathrm{m}$. 2. Protelphidium hofkeri. a. Core 524-12, $224 \mu \mathrm{m}$. b. Edge view, Core 524-12, $227 \mu \mathrm{m}$. 3. Oridorsalis umbonatus. a. Umbilical view, Core 522-29, $358 \mu \mathrm{m}$. b. Edge view, Core 522-29, $282 \mu \mathrm{m}$. c. Spiral view, Core 522-29, $240 \mu \mathrm{m}$. 4. Orthomorphina rohri. Core 522-31, $432 \mu \mathrm{m}$. 5. Plectrofrondicularia lirata. a. Apertural view, Core 522-37, $344 \mu \mathrm{m}$. b. Core 522-37, $360 \mu \mathrm{m}$. c. Core 522-37, $2224 \mu \mathrm{m}$. 


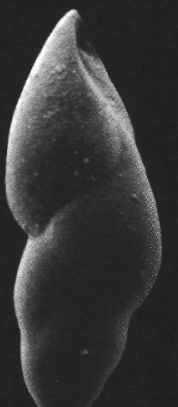

1

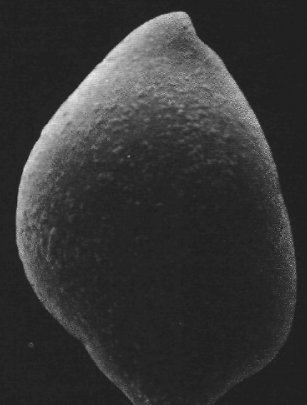

2

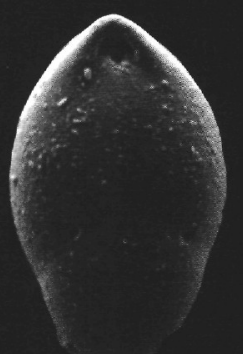

$6 b$
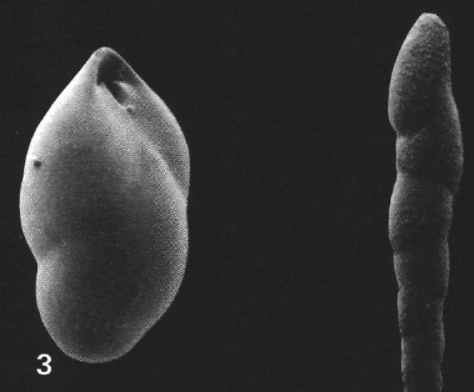

4
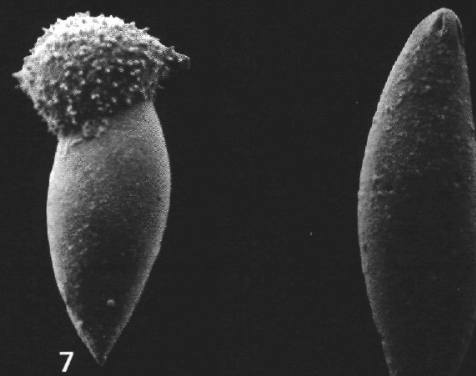

8

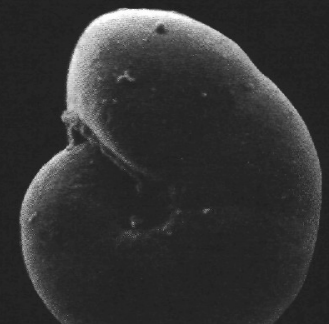

$10 \mathrm{a}$

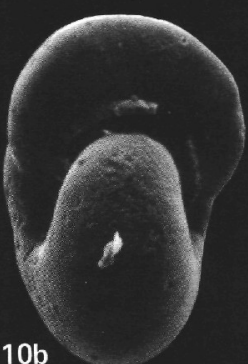

$10 b$

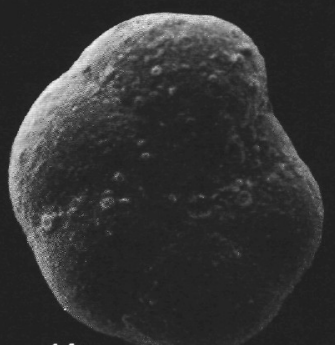

11a
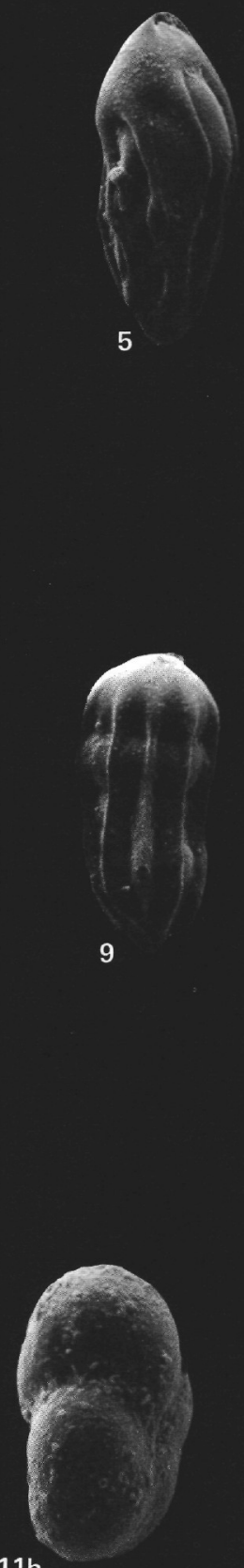

11b

Plate 11. Benthic foraminiferal species. 1. Pleurostomella alternans. Core 522-34, $749 \mu \mathrm{m}$. 2. Pleurostomella sp. cf. P. bierigi. Core 523-31, $336 \mu \mathrm{m}$. 3. Pleurostomella brevis. Core 522-34, $387 \mu \mathrm{m}$. 4. Pleurostomella subcylindrica. Core 522-33, $770 \mu \mathrm{m}$. 5. Pleurostomella sp. 1. Core 522-27, $378 \mu \mathrm{m}$. 6. Pleurostomella sp. 2. a. Core 522-31, $278 \mu \mathrm{m}$. b. Core 522-31, $301 \mu \mathrm{m}$. 7. Pyrulina? sp. Core 523-47, $533 \mu \mathrm{m}$. 8. Pyrulina curvatura. Core 522-32, $674 \mu \mathrm{m}$. 9. Siphogenerina transversa. Core 522-32, $301 \mu \mathrm{m}$. 10. Pullenia sp. 2. a. Core 522-38, $272 \mu \mathrm{m}$. b. Edge view, Core 522-38, $274 \mu \mathrm{m}$. 11. Pullenia jarvisi. a. Core 524-9, $248 \mu \mathrm{m}$. b. Edge view, Core 524-9, $256 \mu \mathrm{m}$. 


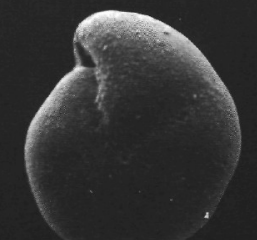

$1 a$

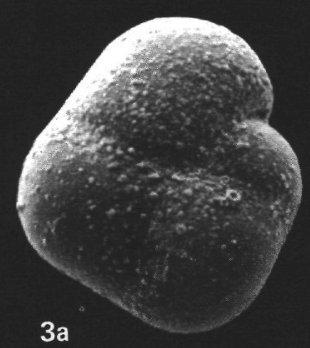

$3 a$

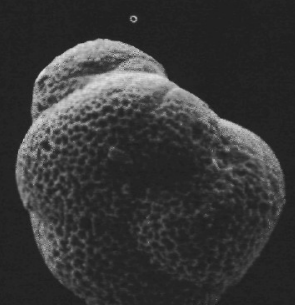

$5 a$

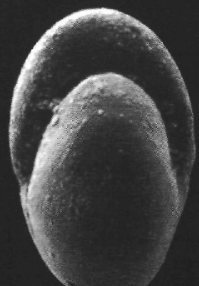

$1 b$

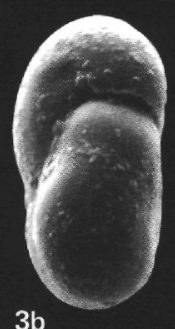

$3 b$

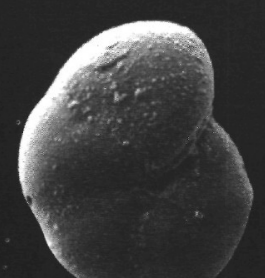

$2 \mathrm{a}$

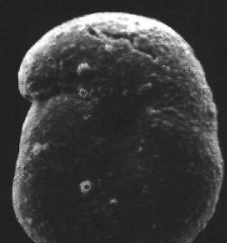

$3 c$

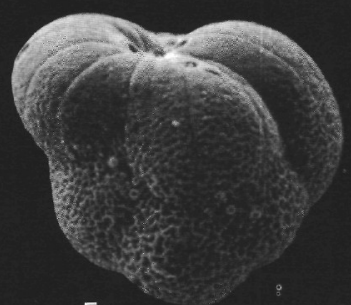

$5 c$

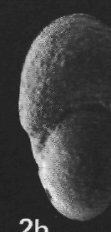

$2 b$

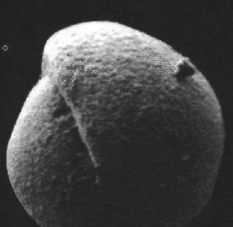

$4 a$

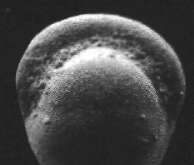

$4 b$

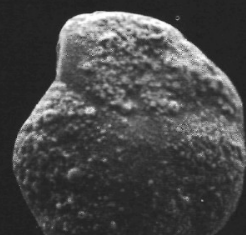

$6 a$
$5 b$
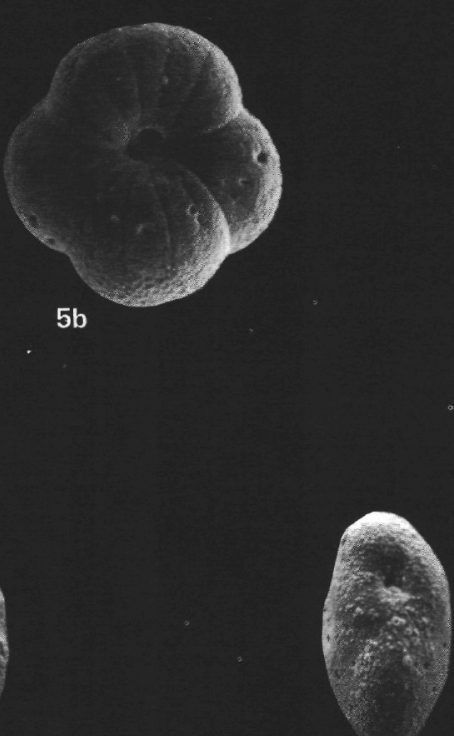

$6 b$

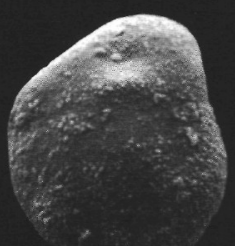

$6 \mathrm{c}$

Plate 12. Benthic foraminiferal species. 1. Pullenia sp. 1. a. Core 522-38, $272 \mu \mathrm{m}$. b. Edge view, Core 522-22, 230 $\mu \mathrm{m}$. 2. Pullenia quinqueloba. a. Core 524-34, $293 \mu \mathrm{m}$. b. Edge view, Core 522-34, $234 \mu \mathrm{m}$. 3. Quadrimorphina profunda. a. Umbilical view, Core 523-28, 270 $\mu \mathrm{m}$. b. Edge view, Core 524-2, $195 \mu \mathrm{m}$. c. Spiral view, Core 523-30, $206 \mu \mathrm{m}$. 4. Pullenia coryelli. a. Core 524-6, 344 $\mu \mathrm{m}$. b. Edge view, Core 524-6, $198 \mu \mathrm{m}$. 5. Quadratobuliminella sp. a. Core 522-36, $162 \mu \mathrm{m}$. b. Apertural view, Core 522-36, $149 \mu \mathrm{m}$. c. Core 522-36, $165 \mu \mathrm{m}$. 6. Stetsonia sp. a. Spiral view, Core 522-31, $194 \mu \mathrm{m}$. b. Edge view, Core 522-32, $211 \mu \mathrm{m}$. c. Spiral view, Core 522-31, $190 \mu \mathrm{m}$. 

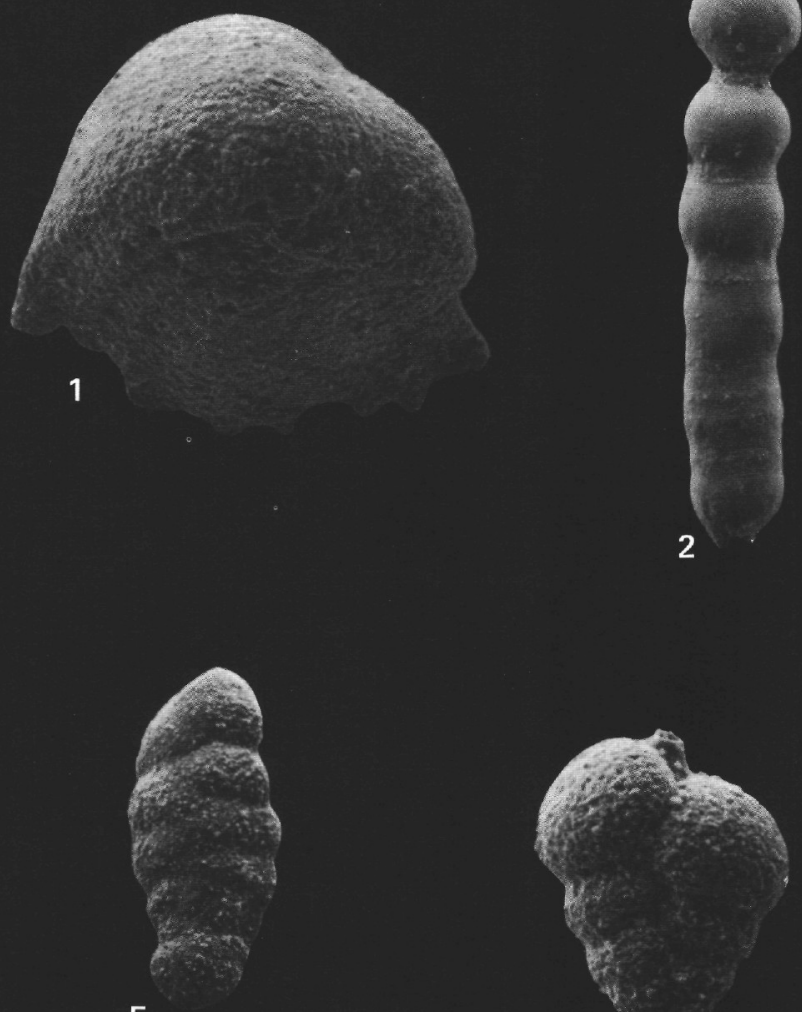

6
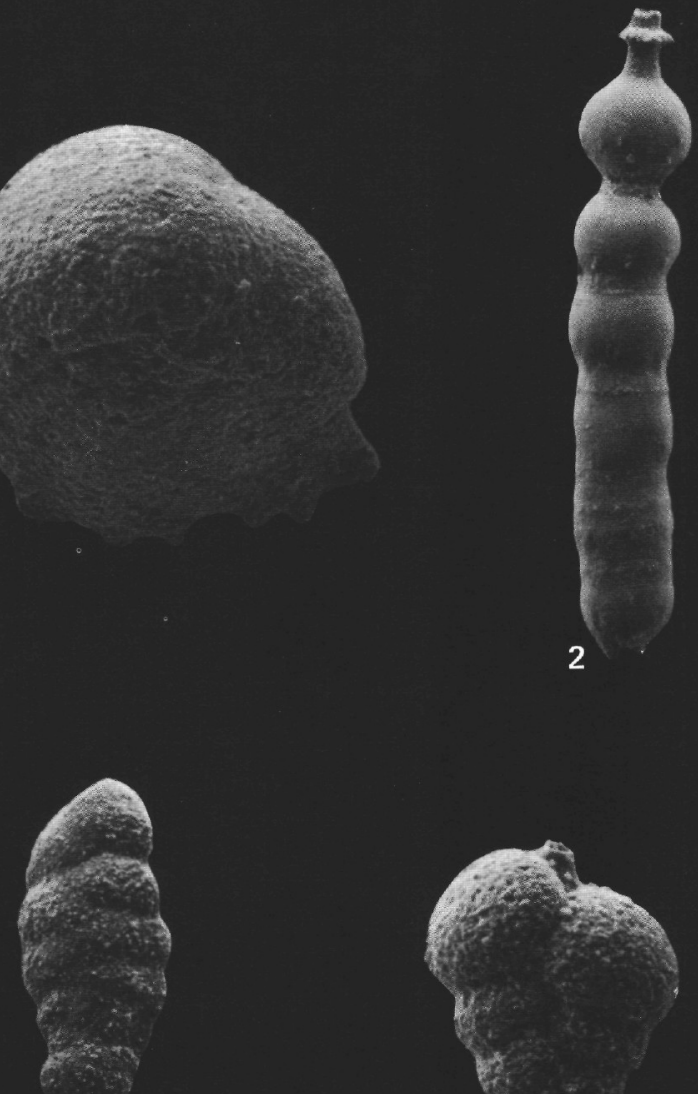

5

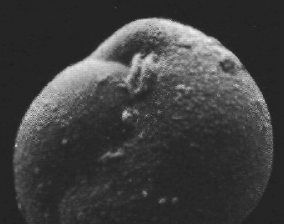

$8 a$

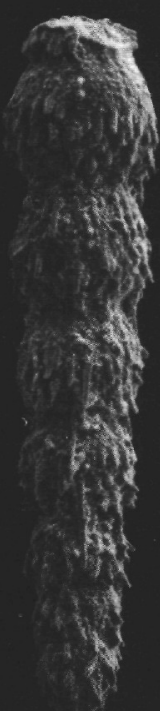

3

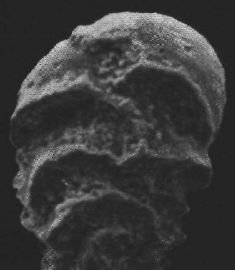

7

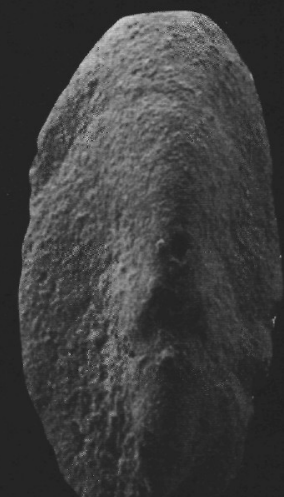

$4 a$

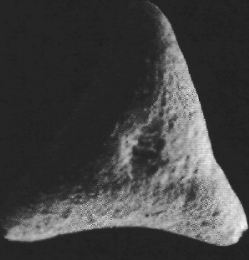

$4 b$

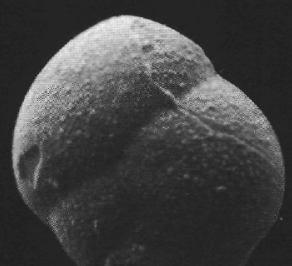

$8 b$

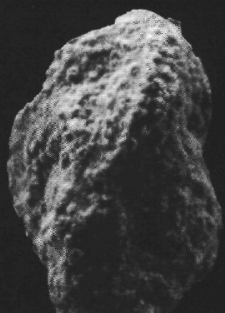

9

Plate 13. Benthic foraminiferal species. 1. Vulvulina spinosa. Core 522-31, $384 \mu \mathrm{m}$. 2. Stilostomella aculeata. Core 523-37, $928 \mu \mathrm{m}$. 3. Stilostomella subspinosa. Core 523-31, $1011 \mu \mathrm{m} .4$ 4. Tritaxia havanensis. a. Core 524-5, $656 \mu \mathrm{m}$. b. Apertural view, Core 524-5, $432 \mu \mathrm{m}$. 5. Spiroplectammina spectabilis. Core 522-11, $440 \mu \mathrm{m}$. 6. Siphotextularia heterostoma. Core 522-34, $227 \mu \mathrm{m}$. 7. Tappanina selmensis. Core 524-3, $272 \mu \mathrm{m}$. 8. Turrilina robertsi. a. Core 522-34, $192 \mu \mathrm{m}$. b. Core 522-34, $162 \mu \mathrm{m}$. 9. Trifarina sp. Core 524-13, $240 \mu \mathrm{m}$. 